\title{
High-dimensional single cell mass cytometry analysis of the murine hematopoietic system reveals signatures induced by ageing and physiological pathogen challenges
}

\author{
Christos Nikolaou ${ }^{1,2,3^{*}}$ (D), Kerstin Muehle ${ }^{1}$, Stephan Schlickeiser ${ }^{2,4}$, Alberto Sada Japp ${ }^{1}$, Nadine Matzmohr ${ }^{1}$, \\ Desiree Kunkel ${ }^{4}$, Marco Frentsch ${ }^{1}$ and Andreas Thiel ${ }^{1}$
}

\begin{abstract}
Background: Immune ageing is a result of repetitive microbial challenges along with cell intrinsic or systemic changes occurring during ageing. Mice under 'specific-pathogen-free' (SPF) conditions are frequently used to assess immune ageing in long-term experiments. However, physiological pathogenic challenges are reduced in SPF mice. The question arises to what extent murine experiments performed under SPF conditions are suited to analyze immune ageing in mice and serve as models for human immune ageing. Our previous comparisons of same aged mice with different microbial exposures, unambiguously identified distinct clusters of immune cells characteristic for numerous previous pathogen encounters in particular in pet shop mice.
\end{abstract}

Results: We here performed single cell mass cytometry assessing splenic as secondary and bone marrow as primary lymphoid organ-derived leukocytes isolated from young versus aged SPF mice in order to delineate alterations of the murine hematopoietic system induced during ageing. We then compared immune clusters from young and aged SPF mice to pet shop mice in order to delineate alterations of the murine hematopoietic system induced by physiological pathogenic challenges and those caused by cell intrinsic or systemic changes during ageing. Notably, distinct immune signatures were similarly altered in both pet shop and aged SPF mice in comparison to young SPF mice, including increased frequencies of memory $T$ lymphocytes, effector-cytokine producing T cells, plasma cells and mature NK cells. However, elevated frequencies of CD4 ${ }^{+} \mathrm{T}$ cells, total NK cells, granulocytes, pDCs, cDCs and decreased frequencies of naïve B cells were specifically identified only in pet shop mice. In aged SPF mice specifically the frequencies of splenic lgM ${ }^{+}$plasma cells, CD8 ${ }^{+} T$ cells and CD4 $4^{+} \mathrm{CD} 25^{+}$Treg were increased as compared to pet shop mice and young mice.

(Continued on next page)

\footnotetext{
* Correspondence: christos.nikolaou@charite.de

${ }^{1}$ Regenerative Immunology and Aging, BIH Center for Regenerative Therapies (BCRT), Charité Universitätsmedizin Berlin, Berlin, Germany

${ }^{2}$ Institute for Medical Immunology, Charité Universitätsmedizin Berlin, Berlin, Germany

Full list of author information is available at the end of the article
}

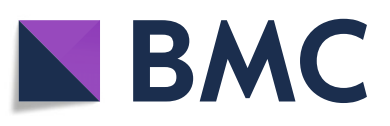

(0) The Author(s). 2021, corrected publication [2021]. Open Access This article is licensed under a Creative Commons Attribution 4.0 International License, which permits use, sharing, adaptation, distribution and reproduction in any medium or format, as long as you give appropriate credit to the original author(s) and the source, provide a link to the Creative Commons licence, and indicate if changes were made. The images or other third party material in this article are included in the article's Creative Commons licence, unless indicated otherwise in a credit line to the material. If material is not included in the article's Creative Commons licence and your intended use is not permitted by statutory regulation or exceeds the permitted use, you will need to obtain permission directly from the copyright holder. To view a copy of this licence, visit http://creativecommons.org/licenses/by/4.0/. The Creative Commons Public Domain Dedication waiver (http:// creativecommons.org/publicdomain/zero/1.0/) applies to the data made available in this article, unless otherwise stated in a credit line to the data. 
(Continued from previous page)

Conclusions: Our study dissects firstly how ageing impacts both innate and adaptive immune cells in primary and secondary lymphoid organs. Secondly, it partly distinguishes murine intrinsic immune ageing alterations from those induced by physiological pathogen challenges highlighting the importance of designing mouse models for their use in preclinical research including vaccines and immunotherapies.

Keywords: Immunoaging, Wild immunology, Adaptive immune system, Innate immune system, Bone microenvironment, Mass cytometry

\section{Background}

Ageing of the immune system is associated with increased risk of infections as well as an increased tendency towards autoimmunity and diverse immunopathologies [1-3]. On the one hand, physiological processes such as cellular senescence, stem and progenitor cell exhaustion as well as genomic instability may represent intrinsic key factors in age-associated alterations of the immune system [4-6]. On the other hand, constant challenges with pathogens and external physical stressors induce changes in the immune system [7-9]. Murine experimental models have been widely used to assess immune ageing related alterations. However, exploring mechanisms of ageing in murine models and translating obtained results to human physiology is challenging. Laboratory mice are characterized by a diminutive lifespan compared to humans and are usually kept under non-physiological clean specific pathogen free (SPF) conditions. We and others have shown that SPF-housed laboratory animals as compared to animals living in more natural 'dirty' environments drastically differ with respect to various phenotypical and functional immune signatures [10-12]. Shielding of the immune system under SPF or germ-free conditions may enable the identification of intrinsic cellular immune alterations. We here applied multidimensional mass cytometry to delineate differences in phenotypic and functional immune signatures in primary and secondary lymphoid organs (bone marrow and spleen, respectively) of old and young SPF mice, as well as pet shop mice from our previous study as the most characteristic mouse group with distinguished immune signatures for numerous previous pathogen encounters. Our analysis identified distinct clusters of leukocytes similarly altered in old SPF mice as well as in pet shop mice. However, specific individual changes were identified in SPF-aged mice as well as in pet shop mice. This emphasizes that, while certain aspects of immune ageing and related diseases may be studied in standard experimental mouse models, common SPF housing settings may have to be adapted in order to translate results to be relevant for a physiological human setting.

\section{Results}

Splenic and bone marrow leukocyte composition in old versus young SPF mice

To elucidate intrinsic cellular induced age-associated immune alterations, we first assessed changes in overall leukocytes subsets in bone marrow and spleen of young (6 months) versus old (20 months) SPF mice. Using manual gating (Supplemental Fig. 1) and unsupervised raw data clustering [13-16] of single live CD $45^{+}$cells, we defined established subsets such as B cells, CD $4^{+}$, $\mathrm{CD}^{+} \mathrm{T}$ and innate cells and compared their counts and frequencies in samples from young and old SPF mice. This analysis allowed us to directly identify phenotypic differences between both SPF groups in spleen and bone marrow (Fig. 1a and d). We then analyzed each immune cluster of three major leukocyte groups: (a) $\mathrm{CD} 45^{+}$

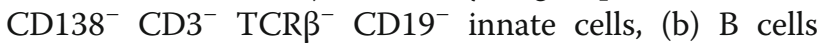
and (c) T cells and identified unique populations according to cell surface markers expression for each group of mice as indicated in the heat maps for spleen and bone marrow (Fig. 1b and e). Stratifying the data from spleen and bone marrow by the relative immune cell composition, only minor differences between young and old mice could be determined (Supplemental Fig. 2). However, slightly reduced frequencies of $\mathrm{CD}^{+} \mathrm{T}$ cells and NK cells could be detected in the spleen of old SPF mice compared to the younger counterparts (Fig. 1a and Supplemental Fig. 2 left ). In contrast, the CD $4^{+} \mathrm{T}$ cell frequencies in the bone marrow were higher in old mice when compared to young SPF mice (Fig. 1d and Supplemental Fig. 2 right ). When comparing absolute numbers by acquisition of a defined volume of the cell suspension, counts in the spleen for $\mathrm{CD} 45^{+}, \mathrm{CD}^{+}, \mathrm{CD}^{+}$and $\mathrm{CD} 8^{+}$ $\mathrm{T}$ cells as well as $\mathrm{CD} 19^{+} \mathrm{B}, \mathrm{NK}$ and $\mathrm{CD} 45^{+} \mathrm{CD} 138^{-}$ $\mathrm{CD}^{-}{ }^{-} \mathrm{TCR}^{-} \mathrm{CD}^{-} 9^{-}$innate cells were similar in both groups (Fig. 1c). In contrast, absolute counts in the bone marrow were significantly higher for $\mathrm{CD} 45^{+}, \mathrm{CD}^{+}$, $\mathrm{CD}^{+}$and $\mathrm{CD}^{+} \mathrm{T}$ cells as well as $\mathrm{CD} 45^{+} \mathrm{CD} 138^{-} \mathrm{CD}^{-}$ $\mathrm{TCR} \beta^{-} \mathrm{CD} 19^{-}$innate cells in old SPF mice, while CD19 ${ }^{+}$ $B$ and NK cells were similar in both groups (Fig. 1f). Altogether, $\mathrm{CD} 45^{+}$and major immune subset absolute counts between young and old SPF mice were similar in the spleen, in contrast to the bone marrow where increased absolute cell numbers indicate the accumulation 


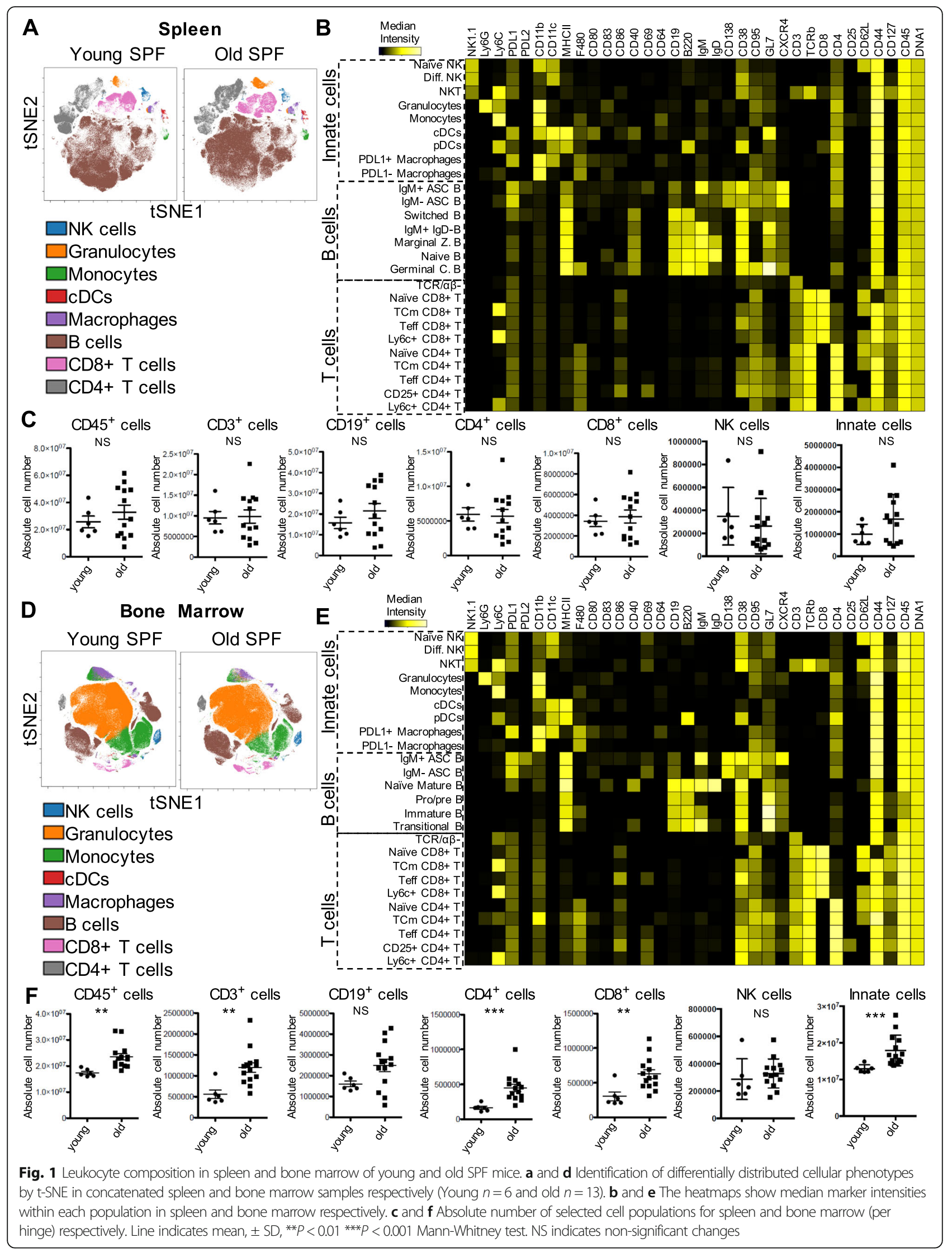


of immune cells in aged bone marrow environment. Based on their frequencies, $\mathrm{CD} 4^{+} \mathrm{T}$ cells were less abundant in the spleen in contrast to the bone marrow of old SPF mice compared to the young SPF mice.

\section{Differentiated innate cells in spleen in old versus young SPF mice}

In order to study age-related changes among innate subsets we analyzed $\mathrm{CD} 45^{+} \mathrm{CD} 138^{-} \mathrm{CD}^{-} \mathrm{TCR}^{-} \mathrm{CD}^{-} 9^{-}$ innate cell populations such as naïve and mature NK cells, granulocytes, monocytes, macrophages, plasmacytoid dendritic cells (pDCs) and conventional dendritic cells (cDCs), as well as their activation associated marker signatures (Fig. 2a, b and Supplemental Fig. 1). We observed significantly lower frequencies of splenic NK cells and specifically a reduction of naive $\mathrm{CD}^{+} \mathrm{L}^{+} \mathrm{NK}$ cells among NK1.1 $1^{+}$cells as well as a minor reduction of macrophages in old animals (Fig. 2c). Furthermore, differentiated classical activated macrophages characterized by $\mathrm{F} 4 / 80^{+}, \mathrm{PD}-\mathrm{L}^{+}$expression, as described by Loke and coworkers [17] were more frequent in old SPF mice compared to the young SPF group (Fig. 2c). In contrast, we found no changes in splenic frequencies of granulocytes (Fig. 2c), pDCs, cDCs and monocytes among young and old SPF mice (Supplemental Fig. 4A). Altogether, distinct innate subsets such as NK cells and macrophages acquired differentiated phenotypes in the spleen of old mice.

\section{Differentiated innate cells in bone marrow in old versus young SPF mice}

To investigate whether myelopoiesis is affected during ageing, we also analyzed the composition of $\mathrm{CD} 45^{+}$ $\mathrm{CD} 138^{-} \mathrm{CD}^{-}{ }^{-} \mathrm{TCR}^{-} \mathrm{CD}^{-} 9^{-}$innate cells in the bone marrow as a primary lymphoid organ (Fig. $2 \mathrm{~d}$ and e). We found no changes in frequencies of granulocytes (Fig. 2f), cDCs and NK cells (Supplemental Fig. 3A) between old and young SPF mice. However, lower frequencies of naïve $\mathrm{CD} 2 \mathrm{~L}^{+} \mathrm{NK}$ cells among NK1.1 $1^{+}$cells and a decrease of macrophages in old SPF mice were demonstrated. In contrast to the results from spleen, we identified significant less pDCs but increased frequencies of monocytes (Fig. 2f). Taken together these data indicate that the hematopoietic generation of granulocytes and cDCs in the bone marrow is maintained over the lifespan of SPF laboratory mice, whereas hematopoiesis and differentiation towards monocytes, differentiated PD-L1 ${ }^{+}$ macrophages and $\mathrm{CD}^{-} 2 \mathrm{~L}^{-}$NK cells (Fig. 2f) are increased with age.

\section{Antibody secreting cells and 'switched' B cells in spleen in old versus young SPF mice}

Previous studies have shown that B cell proliferation and differentiation from lymphoid progenitor to mature B cells is impaired in aged mice compared to young mice $[18,19]$. In order to evaluate age related effects on mature subsets of B cells, we assessed markers such as IgM, IgD, MHC-II, CD40, CD62L, CD80, PD-L1, CD38, GL7, CD95, CXCR4, CD138 and CD127 on B cells (Fig. 3a, b and Supplemental Fig. 1). We found similar frequencies of total $\left(\mathrm{CD} 19^{+} \mathrm{B}_{220^{+}}\right)$and naïve $\left(\mathrm{IgM}^{+} \mathrm{IgD}^{+}\right) \mathrm{B}$ cells in both groups (Fig. 3c), while slightly lower frequencies of marginal zone $\left(\operatorname{IgM}^{+} \operatorname{IgD}{ }^{\text {low }}\right)$ B cells were observed in the older group (Supplemental Fig. 4B). Higher frequencies of antigen-experienced IgD" IgM $^{-}$"switched" B cells were found in old SPF mice, indicating that even under long term SPF conditions a substantial pool of differentiated B cells is formed (Fig. 3c). Notably, old mice showed accumulation of total $\mathrm{CD} 138^{+}$antibody secreting cells (ASCs) and specifically $\operatorname{IgM}^{+} \operatorname{IgD}^{-}$ASCs (Fig. 3c). Germinal center (GC, $\mathrm{GL7}^{+} \mathrm{CD}^{+} 5^{+}$) B cells were found equally low in both groups demonstrating that no acute immune responses were present at the time of analysis (Fig. 3c). In summary, these results demonstrate a significant accumulation of antigenexperienced B cells and particularly $\operatorname{IgM}^{+} \mathrm{IgD}^{-}$ASCs in the spleen of old mice housed under clean SPF conditions.

\section{Decreased pro-B/pre-B cells but increased mature naive $B$} cells in bone marrow in old versus young SPF mice

The literature is contradictory regarding $\mathrm{B}$ cell subset frequencies and numbers in murine bone marrow [18-22]. We wanted to evaluate whether differences in the $\mathrm{B}$ cell composition are a result of age-related changes in B cell development at their place of origin (Fig. 3d-f). We observed similar frequencies of total $\left(\mathrm{CD} 19^{+} \mathrm{B}^{2} 20^{+}\right) \mathrm{B}$ cells but a significant decrease of frequencies in pro-B/pre-B cell $\left(\mathrm{IgM}^{-}, \mathrm{IgD}^{-}, \mathrm{CD} 127^{+}\right)$ compartment (Fig. 3f), but also in immature (IgM ${ }^{\text {low }}$, $\left.\mathrm{IgD}^{-}, \mathrm{CD} 127^{+}\right)$and transitional $\left(\mathrm{IgM}^{\text {high }}, \mathrm{IgD}^{+-}\right.$, $\mathrm{CD}^{2} 2^{-}$) B cells in aged mice (Supplemental Fig. 3B). In contrast, frequencies of mature naïve $\left(\operatorname{IgM}^{+}, \operatorname{IgD}^{+}\right.$, $\mathrm{CD} 127^{-}$) B cells were increased in aged mice (Fig. 3f). Some immune cells such as distinct subsets of memory B- and T-cells as well as plasma cells reside in the bone marrow [23]. In contrast to spleen, we did not observe any significant difference in $\operatorname{IgM}^{+} \mathrm{IgD}^{-}$ ASCs between the two groups (Fig. 3f). However, the frequencies of total $\mathrm{CD} 138^{+} \mathrm{ASCs}$ in the bone marrow were higher in old compared to young mice (Fig. 3f). Taken together, despite the reduction in pro-B/pre- $B$ cell compartment, the frequency of mature naïve $B$ cells in bone marrow was higher than expected, while $\operatorname{IgM}^{+} \operatorname{IgD}^{-}$ASCs were more abundant in the spleen instead of the bone marrow of old SPF mice. 
A

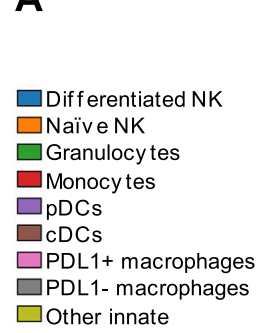

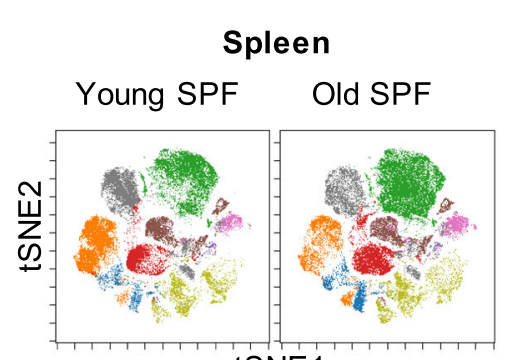

tSNE1
B

Intensity

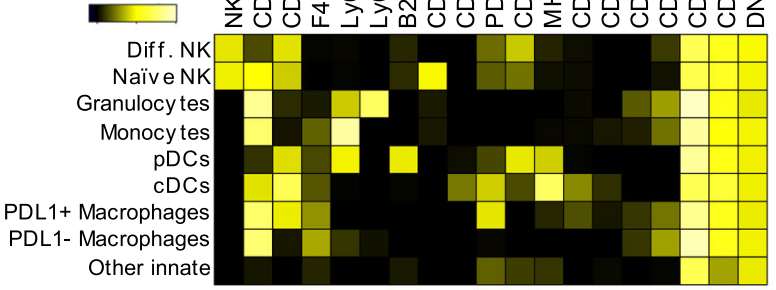

C

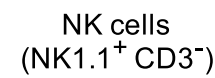

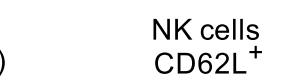

Granulocytes
$\left(\mathrm{CD} 11 \mathrm{~b}^{+}\right.$Ly6G $\left.^{+}\right)$

Macrophages
$\left(\mathrm{CD} 11 \mathrm{~b}^{+} \mathrm{F} 4 / 80^{\mathrm{hi}}\right)$

Macrophages

$\left(\mathrm{PD}-\mathrm{L} 1^{+}\right.$)
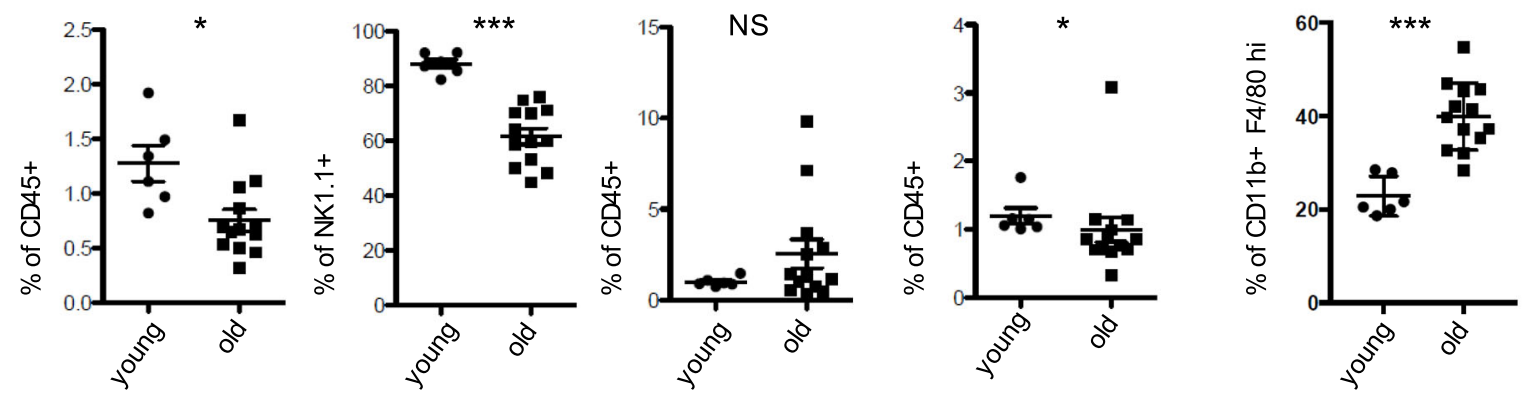

D

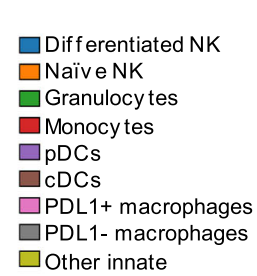
$\square$ Other innate

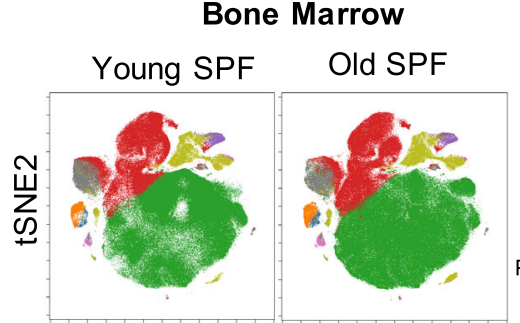

tSNE1
E Median
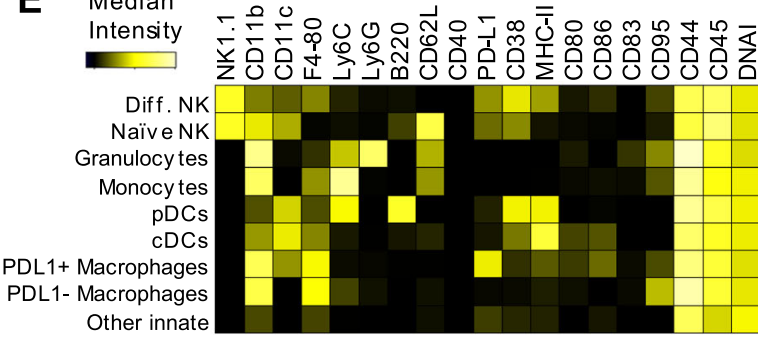

F NK cells $\mathrm{CD}^{2} \mathrm{~L}^{+}$

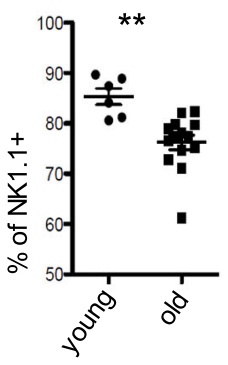

pDCs $\left(\mathrm{CD} 11 \mathrm{c}^{+} \mathrm{B}_{220}{ }^{+}\right.$ MHCll hi)

Granulocytes
$\left(\mathrm{CD} 11 \mathrm{~b}^{+}\right.$Ly6G $\left.^{+}\right)$

$\left.\begin{array}{c}\text { Monocytes } \\ \left(\mathrm{CD} 11 \mathrm{~b}^{+} \text {Ly6C }\right. \\ \text { hi }\end{array}\right)$

Macrophages
$\left(\mathrm{CD} 11 \mathrm{~b}^{+} \mathrm{F} 4 / 80 \mathrm{hi}\right)$

Macrophages

$\left(\mathrm{PD}-\mathrm{L1}^{+}\right.$)
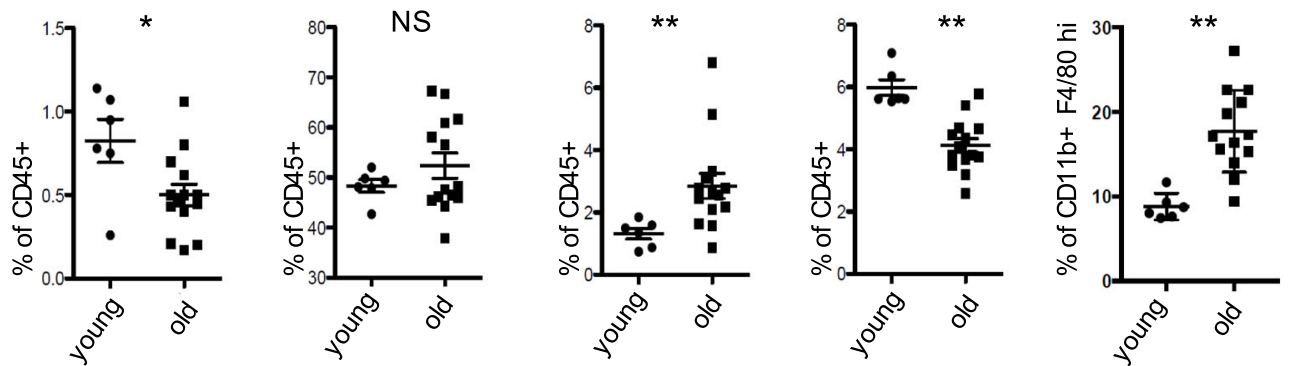

Fig. 2 Age related changes in the innate cell composition in spleen and bone marrow of SPF mice. a and $\mathbf{d}$ Identification of differentially distributed cellular phenotypes by t-SNE in concatenated spleen and bone marrow samples respectively (Young $n=6$ and old $n=13$ ). $\mathbf{b}$ and $\mathbf{e}$ The heatmaps show median marker intensities within each population in spleen and bone marrow respectively. $\mathbf{c}$ and $\mathbf{f}$ Selected innate populations were gated according to established lineage markers (Supplemental Fig. 1 for gating strategy). Line indicates mean, $\pm \mathrm{SD},{ }^{*} P<0.05,{ }^{* *} P<0.01{ }^{* * *} P<0.001$ MannWhitney test. NS indicates non-significant changes

Age-related increase of T effector and central memory subsets

Involution of the thymus and the associated diminished output of naive $\mathrm{T}$ cells represents one of the most recognized changes in the immune system with age [2426]. We delineated $\mathrm{CD}^{+}$and $\mathrm{CD}^{+} \mathrm{T}$ cells in naïve (Tnaive, CD62L $\mathrm{CD}^{+} \mathrm{C}^{-}$), effector (Teff, CD62L ${ }^{-}$ $\mathrm{CD}_{4} 4^{+}$), and central memory (TCM, CD62L ${ }^{+} \mathrm{CD}_{4} 4^{+}$) $\mathrm{T}$ 


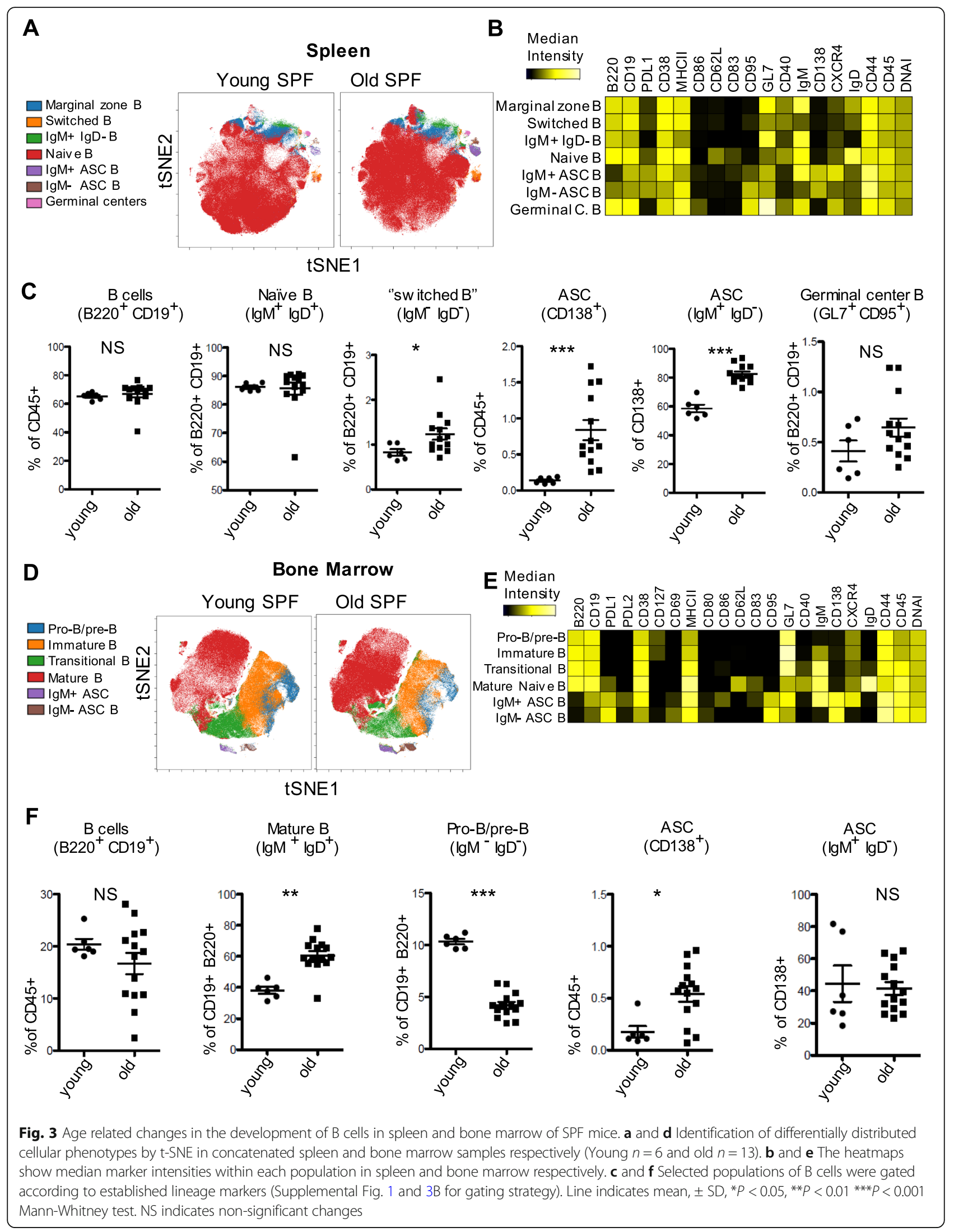




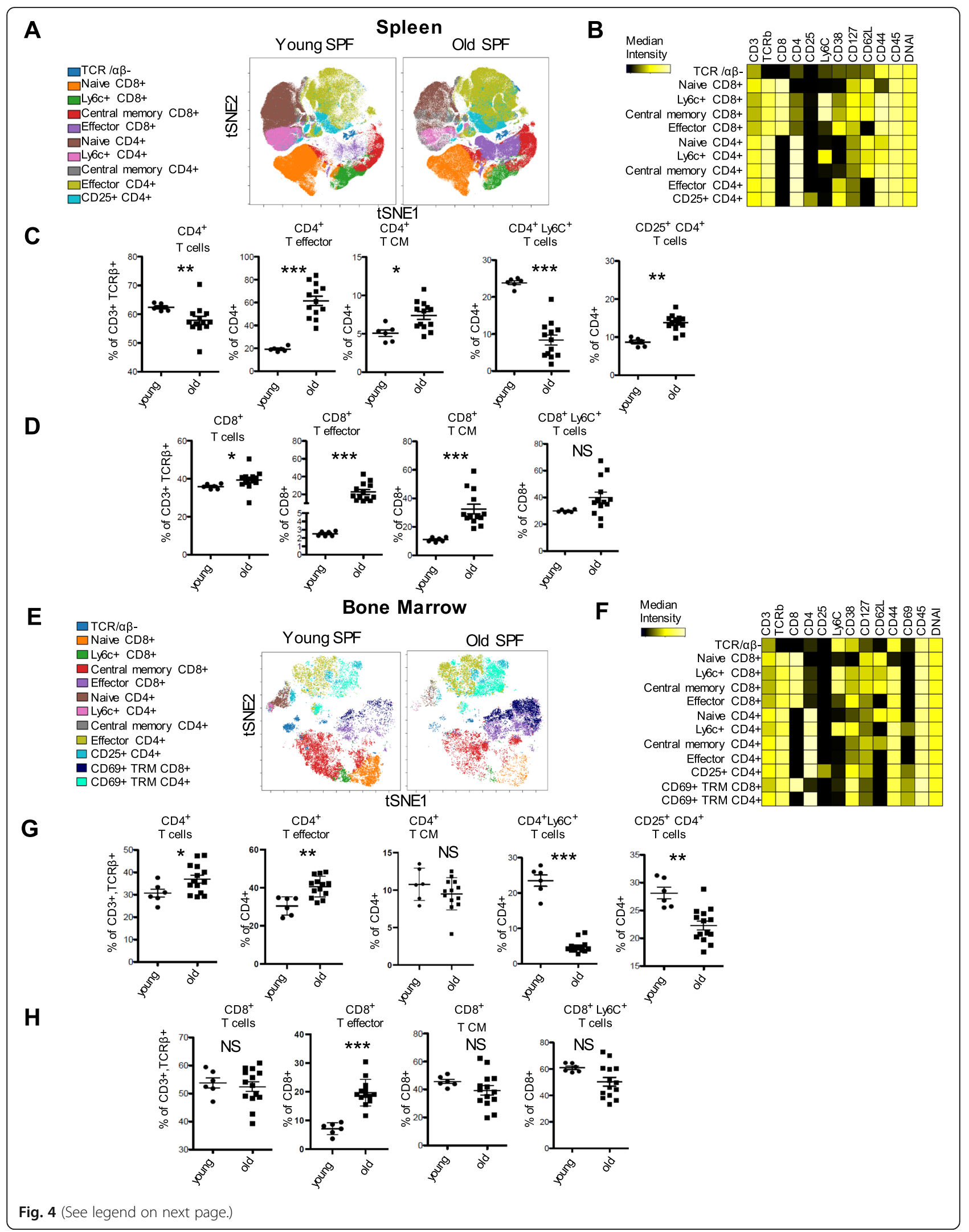


(See figure on previous page.)

Fig. 4 Age related changes in T cell subsets in spleen and bone marrow of SPF mice. a and e Identification of differentially distributed cellular phenotypes by t-SNE in concatenated spleen and bone marrow samples respectively (Young $n=6$ and old $n=13$ ). $\mathbf{b}$ and $\mathbf{f}$ The heatmaps show median marker intensities within each population in spleen and bone marrow respectively. $\mathbf{c}$ and $\mathbf{g}$ Selected populations of CD4+ T cells. $\mathbf{d}$ and h Selected populations of CD8+ T cells. Populations of T cells were gated according to established lineage markers (Supplemental Fig. 1 and 3 for gating strategy). Line indicates mean, $\pm \mathrm{SD},{ }^{*} P<0.05,{ }^{* *} P<0.01{ }^{* * *} P<0.001$ Mann-Whitney test. NS indicates non-significant changes

cells according to expression of CD44 and CD62L (Fig. 4a, b and Supplemental Fig. 1). Old SPF mice revealed the lowest frequencies of $\mathrm{CD}_{4}^{+} \mathrm{T}$ cells in the spleen in comparison to young SPF mice. Specifically, higher frequencies of effector $\mathrm{CD} 4^{+} \mathrm{T}$ cells and central memory $\mathrm{CD}^{+} \mathrm{T}$ cells were observed in the spleen of old mice (Fig. 4a and c). In addition, $\mathrm{Ly}_{6 \mathrm{C}}{ }^{+} \mathrm{CD} 4^{+} \mathrm{T}$ cells were decreased in old mice, indicating an increase in Th1 memory precursor cells with higher survival and proliferative capacities [27]. High CD25 expression on murine $\mathrm{CD}^{+} \mathrm{T}$ cells predominantly characterizes regulatory $\mathrm{T}$ cells, which were increased in the old SPF mice in comparison to the young SPF animals (Fig. 4c).

In contrast to $\mathrm{CD} 4^{+} \mathrm{T}$ cells, old SPF mice exhibited significantly higher frequencies of total $\mathrm{CD}^{+} \mathrm{T}$ cells (Fig. 4d). Analogous to $\mathrm{CD}^{+}{ }^{+} \mathrm{T}$ cells, old mice displayed more effector and central memory cells in their $\mathrm{CD}^{+} \mathrm{T}$ cell compartment (Fig. 4a and d). Since Ly6C is known to be expressed on subsets of memory $\mathrm{CD}^{+} \mathrm{T}$ cells $[28$, 29 ], we expected higher frequencies in the old group, which exhibited the largest $\mathrm{CD}^{+}$effector and central memory $\mathrm{T}$ cell compartments. Surprisingly and in contrast to $\mathrm{CD}^{+} \mathrm{T}$ cells, we observed no significant differences between old and young $\mathrm{Ly}^{6} \mathrm{C}^{+} \mathrm{CD} 8^{+} \mathrm{T}$ cells in the spleen (Fig. 4d). In summary, these results indicate an overall increase of "immunologically experienced" $\mathrm{CD}^{+}$and $\mathrm{CD}_{4}^{+} \mathrm{T}$ lymphocytes in the spleen of old SPF mice compared to young SPF mice.

\section{Effector, central memory and $\mathrm{CD} 69^{+}$tissue resident memory bone marrow $T$ subsets in old versus young SPF mice}

Next we wanted to study age-related changes of $\mathrm{T}$ cells in the bone marrow representing a site for migration or selective retention of subsets of distinct memory $\mathrm{T}$ cell subsets [30-32]. For that purpose, $\mathrm{T}$ cell subsets were assessed in the bone marrow of young and old SPF mice (Fig. 4e and $\mathrm{f}$ ). Effector $\mathrm{CD}^{+} \mathrm{T}$ cells were highly increased in the bone marrow of old SPF mice (Fig. $4 \mathrm{e}$ and g). Notably, frequencies of central memory CD4 ${ }^{+} \mathrm{T}$ cells remained unaffected in old SPF mice in contrast to the spleen, while $\mathrm{Ly}_{6 \mathrm{C}}{ }^{+} \mathrm{CD}_{4}^{+} \mathrm{T}$ cells were reduced as demonstrated before in the spleen (Fig. 4g). In contrast to the spleen, CD25 $5^{+} \mathrm{CD} 4^{+} \mathrm{T}$ cells were reduced in the bone marrow of old SPF mice in comparison to their young SPF counterparts (Fig. 4g). We detected significantly elevated effector $\mathrm{CD}^{+} \mathrm{T}$ cells in bone marrow of old mice (Fig. 4e and h). Central memory and Ly6C ${ }^{+}$ $\mathrm{CD}^{+} \mathrm{T}$ cells showed no significant changes between the groups (Fig. 4h). Bone marrow tissue resident (TRM) $\mathrm{CD}^{+}$and $\mathrm{CD}^{+} \mathrm{T}$ cells were identified based on residency marker CD69 expression [31, 33] (Supplemental Fig. 3D). Both $\mathrm{CD}^{+}$and $\mathrm{CD}^{+} \mathrm{CD}^{+} 9^{+} \mathrm{CD}^{+} 2 \mathrm{~L}^{-} \mathrm{CD} 44^{+}$ tissue resident memory $\mathrm{T}$ cells (TRM) were increased in the old group (Fig. 4e-f and Supplemental Fig. 3D-E). In summary, these results show a decrease of CD $25^{+} \mathrm{CD} 4^{+}$ $\mathrm{T}$ cells and support a gradual increase of differentiated $\mathrm{CD}^{+}$Teff and TRM as well as $\mathrm{CD}^{+}$Teff and TRM lymphocytes in the bone marrow with increasing age.

\section{Cytokine expression of $\mathrm{CD} 4^{+}$and $\mathrm{CD} 8^{+} \mathrm{T}$ cells in spleen of old versus young SPF mice}

Compared to young SPF mice, old SPF mice showed higher frequencies of antigen-experienced $\mathrm{T}$ cells in the spleen. To obtain more insights into the functional diversity of these $\mathrm{T}$ cells, we assessed the production of effector cytokines (IFN- $\gamma$, IL-2, TNF- $\alpha$, IL-4 \& IL-10) as well as CD40L (CD154) and lysosomal-associated membrane protein 1 (CD107a) expression after $5 \mathrm{~h}$ polyclonal stimulation (with phorbol-myristate-acetate and ionomycin) (Fig. 5a and c). Old SPF mice contained significantly higher frequencies of IL2-, IL10-, IL4- and IFN- $\gamma-$ producing $\mathrm{CD}^{+} \mathrm{T}$ cells as compared to young SPF mice (Fig. 5b). In contrast, TNF- $\alpha$-producing $\mathrm{CD}^{+} \mathrm{T}$ cells remained similar in both groups (Fig. 5b). Taken together, these results are in line with the phenotypic analysis described above demonstrating an increase in effector and central memory $\mathrm{CD}^{+} \mathrm{T}$ cells in the spleen of old SPF mice (Fig. 4a-c). The reduction in frequency of $\mathrm{CD}_{40 \mathrm{~L}^{+}} \mathrm{CD}^{+} \mathrm{T}$ cells was accompanied by an increase of cytotoxic CD $107^{+} \mathrm{CD}^{+} \mathrm{T}$ cells in the aged SPF mice (Fig. 5b). In a similar manner, splenic effector cytokine-producing $\mathrm{CD}^{+} \mathrm{T}$ cells were significantly increased in old mice (Fig. 5d). Interestingly, CD40L ${ }^{+}$ helper-type $\mathrm{CD}^{+} \mathrm{T}$ cells remained similar in both groups, while cytotoxic $\mathrm{CD} 107^{+} \mathrm{CD}^{+} \mathrm{T}$ cells were increased in aged mice (Fig. $5 \mathrm{c}$-d). Using Boolean gating, we detected higher frequencies of poly-functional $\mathrm{CD}^{+}$ as well as $\mathrm{CD}^{+} \mathrm{T}$ cells in old mice (Supplemental Fig. 5). In conclusion, changes in cytokine profiles of $\mathrm{CD}^{+}$and $\mathrm{CD}^{+} \mathrm{T}$ cells in the spleen correlate with the decline of naïve $\mathrm{T}$ cells and show an increase in specific effector $\mathrm{T}$ cell subsets in old SPF mice. 


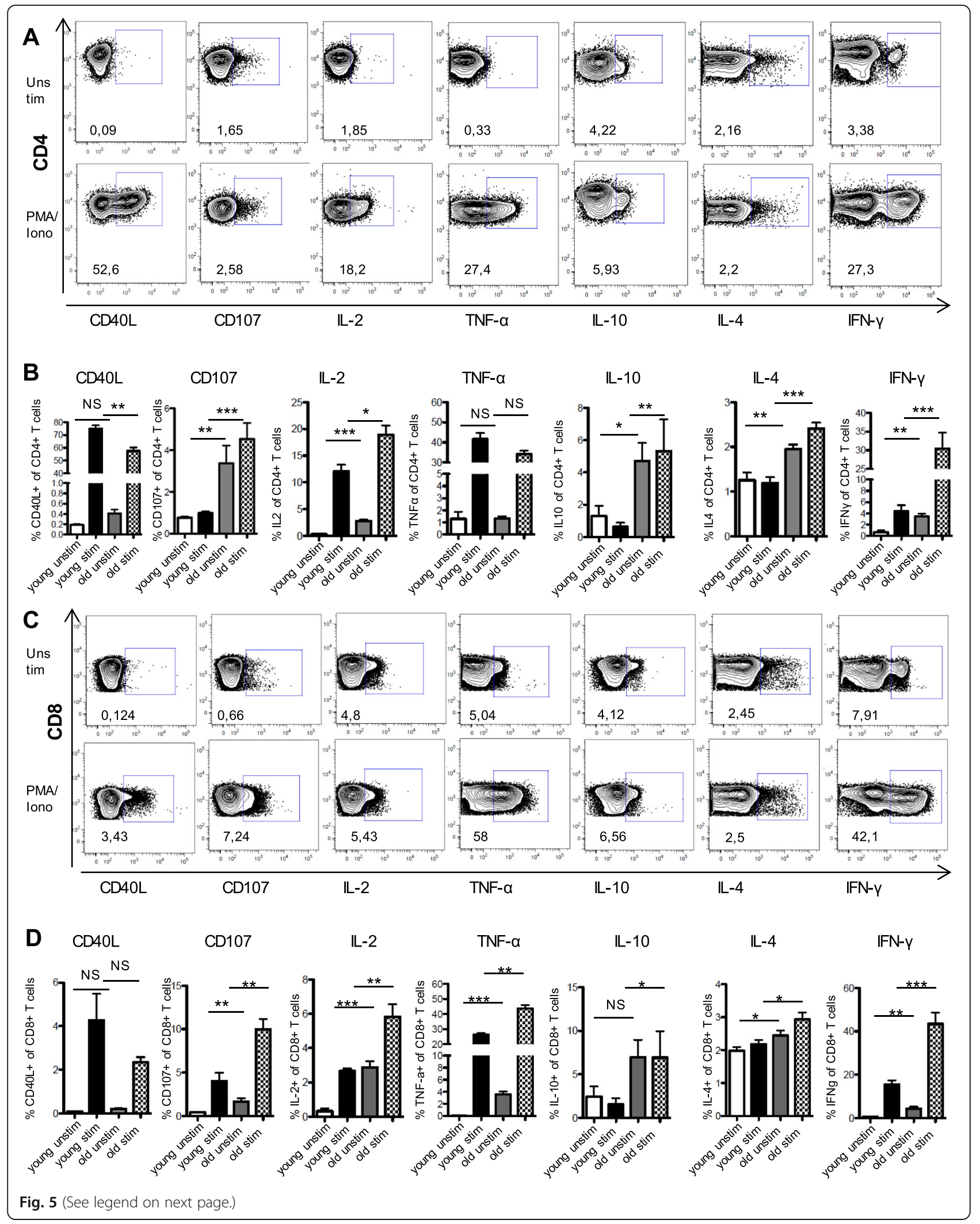


(See figure on previous page.)

Fig. 5 Cytokine secretion profile of CD4+ and CD8+ T cells is altered according to age in spleen of SPF mice. a and c Contour plots showing the cytokine gates for CD4+ (a) and CD8+ T cells (c) in unstimulated and 5 hours, phorbol-myristate-acetate and ionomycin stimulated samples from a representative old SPF mouse spleen sample. $\mathbf{b}$ and $\mathbf{d}$ Summary of the frequencies of cytokine-positive cells in CD4+ (b) and CD8+ T cells (d) ${ }^{*} P<0.05$, ${ }^{*} P<0.01,{ }^{* *} P<0.001$ Mann-Whitney test. NS indicates non-significant changes. (Young $n=6$ and old $n=13$ )

\section{Immune cell signatures in the spleen of pet shop versus} old SPF mice

Our last comprehensive assessment of the murine immune system by comparing mice of same age in our murine housing facilities with potentially different microbial exposures, namely SPF laboratory mice, SPF mice housed for 2 months under non-SPF conditions, mice bred in quarantine, and pet shop mice unambiguously identified distinct clusters of myeloid and lymphoid cells that are characteristic for numerous previous pathogen encounters in particular in pet shop mice [10]. We next compared data sets on the composition of splenic cells isolated from pet shop mice from our recent study [10] as the most characteristic mouse group with distinguished immune signatures for numerous previous pathogen encounters to the data sets obtained here from old and young SPF mice (Fig. 6a-c and Supplemental Fig. 4). Due to perpetual pathogen challenges pet shop mice should at least partially serve as a model for physiological age-associated immune changes. On the one hand, pet shop mice had the highest frequencies of splenic innate subsets such as total NK cells, granulocytes, pDCs, cDCs and monocytes compared to both young and old SPF mice (Fig. $6 \mathrm{~b}$ and Supplemental Fig. 4A). Moreover, frequencies of marginal zone (MZ), $\mathrm{IgM}^{-} \mathrm{IgD}^{-}$"switched" B cells (Fig. 6b and Supplemental Fig. 4B) and total CD $138^{+}$ASCs (Fig. $6 \mathrm{~b}$ and c) were the highest in the pet shop mice. Significant higher frequencies of total $\mathrm{CD}^{+}{ }^{+} \mathrm{T}$ cells, $\mathrm{CD}^{+}{ }^{+}$central memory, $\mathrm{CD} 8^{+}$ effector and $\mathrm{CD}^{+} \mathrm{Ly} 6 \mathrm{C}^{+} \mathrm{T}$ cells were also observed in the pet shop mice among all three groups (Fig. $6 \mathrm{~b}$ and Supplemental Fig. 4C). On the other hand, pet shop mice displayed reduced frequencies of naïve $\mathrm{CD}^{2} 2 \mathrm{~L}^{+} \mathrm{NK}$ cells, naïve $\mathrm{CD}^{+}$and naïve $\mathrm{CD}^{+} \mathrm{T}$ cells equally to the old SPF mice (Fig. 6b and c). Pet shop mice, displayed most reduced frequencies of $\mathrm{CD} 138^{+} \mathrm{IgM}^{+} \mathrm{IgD}^{-}$ASCs as well as $\mathrm{CD}^{+}{ }^{+} \mathrm{CD} 25^{+} \mathrm{T}$ cells (Fig. 6b and c), naïve $\mathrm{IgM}^{+} \mathrm{IgD}^{+} \mathrm{B}$ cells, total $\mathrm{CD}^{+} \mathrm{T}$ cells and total $\mathrm{CD}^{+} \mathrm{T}$ cells when compared to both SPF groups (Fig. 6b and Supplemental Fig. 4D). In summary, naïve subsets such as naïve $\mathrm{CD} 6 \mathrm{~L}^{+} \mathrm{NK}, \mathrm{CD}^{+}$and $\mathrm{CD}^{+} \mathrm{T}$ cells were similarly decreased in old SPF and pet shop mice while naïve $B$ cells were reduced only in the pet shop group. Interestingly, even though both old SPF mice and pet shop mice showed increased experienced $B$ cell subsets, old SPF mice accumulated more $\mathrm{CD}_{138^{+}} \mathrm{IgM}^{+} \mathrm{IgD}^{-}$ASC B cells (Fig. 6c), which may develop even in the absence of germinal centers and can be retained within the spleen
[34]. Thus, old mice kept under SPF conditions have a mature immune system along with some typical immune ageing signatures like decline of frequencies of total $\mathrm{CD}^{+} \mathrm{T}$ cells as well as increase of total and central memory $\mathrm{CD}^{+} \mathrm{T}$ cells as well as Treg frequencies in comparison to the immune system of pet shop mice (Fig. 6b-c and Supplemental Fig. 4C-E). In contrast, pet shop mice facing perpetual physiological microbial challenges demonstrate a variety of immune cells such as innate subsets like granulocytes, NK cells, pDCs, cDCs and monocytes as well as $\mathrm{CD}_{138^{+}} \mathrm{IgM}^{-} \mathrm{IgD}^{-} \mathrm{ASC} \mathrm{B}$ cells.

\section{Discussion}

Ageing of the immune system is a multifactorial process, driven by intrinsic and extrinsic mechanisms such as cellular senescence, stem cell exhaustion, genomic instability but also physiological acute and chronic pathogen challenges. In parallel, accumulating evidence suggests that important physiological parameters such as microbiome configuration, diet, sterile derivation and husbandry practices can modulate the mammalian innate and adaptive immune system by regulating a delicate balance of pro- and anti-inflammatory responses [10, 11, 35-38]. We here examined individual immune signatures of healthy young and old SPF mice and compared these to the immune signatures of healthy pet shop mice. One of our aims was to elucidate in parallel innate and adaptive immune differences between young and old SPF animals not only in the spleen but also in the bone marrow thereby covering secondary and primary lymphoid organs respectively. High-dimensional single cell mass cytometry permitted to overcome experimental limitations by enabling the monitoring of multiple cell subsets or correlates within our study carrying the potential to understand the immune networking at a certain time point at a deeper level. Additionally, we aimed to dissect possible intrinsic and extrinsic consequences onto the immune maturation and ageing. Shielded partially from pathogens and commensals old SPF mice may partly be suitable to assess age-associated changes in the immune system that are concerted by immune cell or system intrinsic mechanisms. While germ-free mice would fit best to assess such intrinsic immune ageing alterations, it has been demonstrated already more than 50 years ago that they exhibit longer life-spans as compared to control mice [39]. More recently it has been demonstrated that aged gut microbiota isolated 


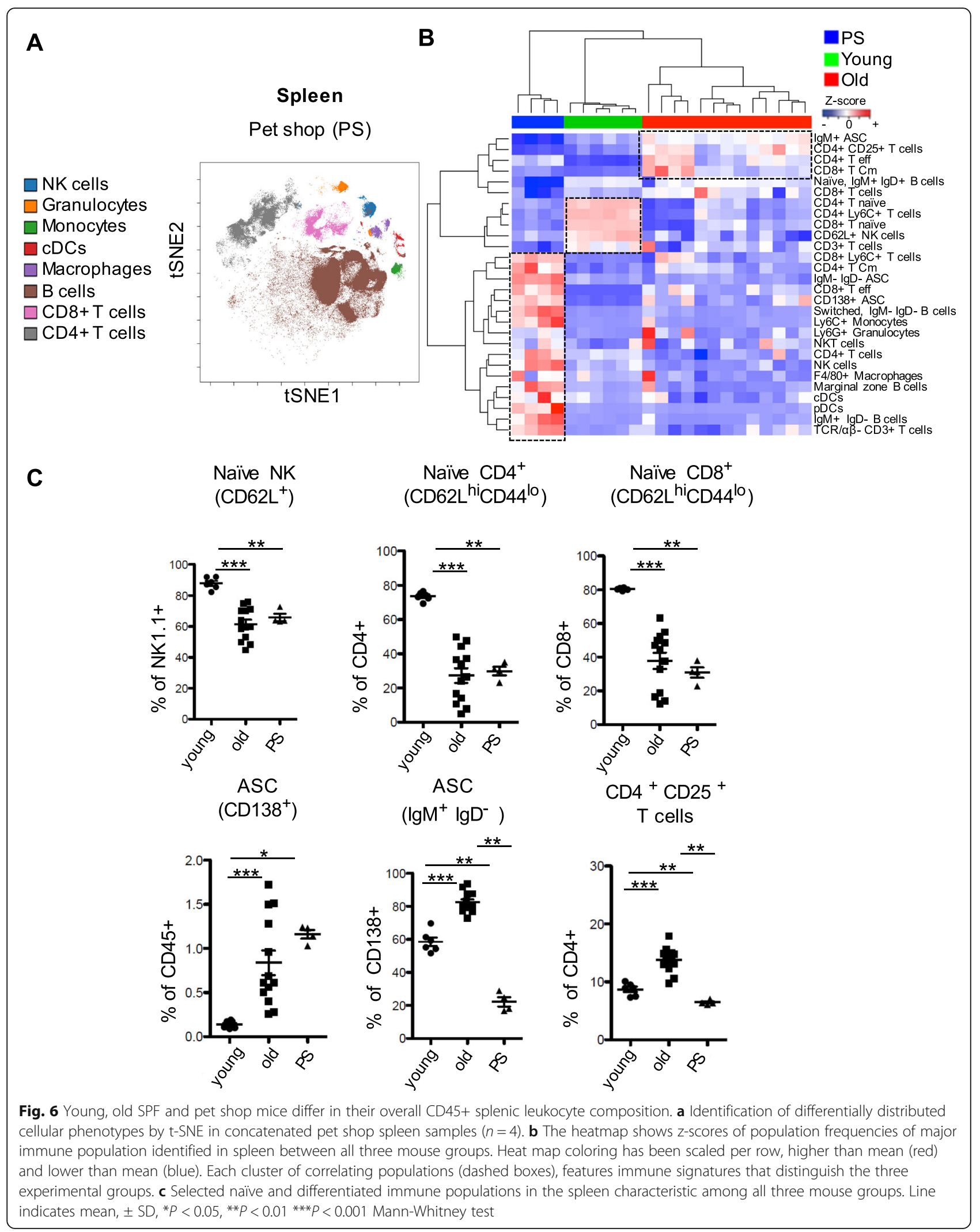


from mice bred under conventional conditions can contribute to systemic inflammageing [40]. We could delineate distinctly altered immune signatures in adult pet shop mice from alterations in old SPF mice most likely resulting from cell intrinsic or systemic changes during ageing. All of our mice weighted over $25 \mathrm{~g}$ and were considered adults. Even though we could not precisely identify the age of pet shop mice we considered them as adults, in the range of 4-8 months old, based on some of their physical attributes such as weight, fur and dental anatomy [41-44]. In particular, we analyzed and categorized three major immune clusters, 1) innate subsets, 2) $B$ cell subsets and 3) T cell subsets.

Older SPF mice exhibited alterations such as less naïve CD62 $\mathrm{L}^{+} \mathrm{NK}$ cells and more differentiated $\mathrm{CD}^{2} \mathrm{~L}^{-} \mathrm{NK}$ cells and PD- $\mathrm{L}^{+}$macrophages both in the spleen and bone marrow in contrast to young SPF mice. CD62L ${ }^{-}$ differentiated NK cells have been already described in mice and humans [45]. Likely due to endogenous accumulation of natural inflammatory events such as oxidative metabolism which leads to increased reactive oxygen species (ROS) and consequently oxidative stress and cellular debris [46] in combination with few microbial encounters present in our SPF facility, more NK cells and classically activated macrophages acquired such a differentiated phenotype in old SPF mice. Such differentiated innate $\mathrm{CD} 6 \mathrm{~L}^{-} \mathrm{NK}$ cells may resign in the bone marrow. We hypothesized that similar to T cells, expression of residency marker CD69 known for tissue retention could also be a mechanism that could retain NK cells in the bone marrow. Interestingly, we have not found a significant difference among $\mathrm{CD}^{+} 9^{+} \mathrm{CD}_{2} \mathrm{~L}^{-}$ NK cells in the bone marrow of young vs old SPF mice (Supplementary Fig. 3A). On the one hand, $\mathrm{CD}^{+} 9^{+} \mathrm{NK}$ cells have been shown to increase in the bone marrow of mice and peaked $72 \mathrm{~h} \mathrm{MHV-3} \mathrm{post-infection} \mathrm{[47]} \mathrm{which}$ would support our observations that no acute immune responses were present at the time of analysis. Even though CD69 expression has been reported in NK bone marrow resident cells the ageing murine tissue resident NK cells can present specific characteristics that involve additional/alternative resident mechanisms for example expression of chemokine receptors CXCR6, CCR5, CCL3 and CXCL12 [48-50].

Overall in the innate subsets, the comparison of the spleen data among all three mouse groups revealed that the pet shop mice had the highest abundancy of granulocytes, pDCs, cDCs and monocytes, indicating better equipped first lines of defense adapted against a multitude of potential pathogens, including viruses, bacteria and endoparasites.

We revealed extensive and profound changes not only in innate but also adaptive immune cell lineages specifically in distinct subsets of effector/memory B cells. In the bone marrow, altered B lymphopoiesis such as distinctly diminished frequencies of pro-B/pre-B cell cells in old mice is likely resulting from the loss of B-lineage precursors, which is in line with the results from Miller and Allmann et al. [19]. Despite this, numbers and frequencies of mature naïve $\operatorname{IgM}^{+} \operatorname{IgD}^{+} \mathrm{B}$ cells in bone marrow were higher in old compared to young SPF mice. In contrast, numbers and frequencies of naïve $\operatorname{IgM}^{+} \operatorname{IgD}^{+} \mathrm{B}$ cells in the spleen were similar between young and old SPF mice. This is in line with other studies reporting a decline in pre- $B$ cells in aged mice without a decrease in the number of naïve $\operatorname{IgM}^{+} \operatorname{IgD}^{+} \mathrm{B}$ cells $[18,22,51]$. The increase of mature naïve $\operatorname{IgM}^{+} \operatorname{IgD}^{+} \mathrm{B}$ cells in old SPF mice can be justified by reduction of positive and negative selection mechanisms that normally regulate the pre-B-to-B cell transition thus allowing more $\mathrm{B}$ cells to escape selection and tolerance promoting possibly ageassociated autoimmune diseases [21, 52]. Notably, old SPF in contrast to young SPF mice exhibited more ASCs both in spleen and bone marrow, whereas physiological low frequencies of germinal center B cells were equal in spleen for both SPF mouse groups. Interestingly, old SPF in contrast to pet shop animals showed accumulation of single $\operatorname{IgM}^{+}$ASCs in the spleen. Bohannon and coworkers showed that $\operatorname{IgM}^{+}$ASCs are primarily retained within the spleen and can develop even in the absence of germinal centers [34]. Consequently, the increase of $\mathrm{IgM}^{+}$ASCs in old SPF mice can be explained by considering a long life-time under lack of firstly corresponding $\mathrm{T}$ cells and secondly direct microbial stimuli, both crucial for a broad variety of ASCs and isotype switch. This effect strongly suggests that even though total ASCs were elevated in both old SPF and pet shop mice, the pet shop mice had developed a broad variety of antigen experienced $\mathrm{B}$ cells, demonstrated by low frequencies of naïve $B$ cells and high frequencies of $\mathrm{CD}_{138^{+}} \mathrm{IgD}^{-} \mathrm{IgM}^{-}$ ASCs instead of $\mathrm{CD}_{138^{+}} \mathrm{IgD}^{-} \mathrm{IgM}^{+}$ASCs developed in old SPF mice, representing most likely the pet shop's mice natural exposure to a plethora of microbes.

From the T lymphocytes' perspective, aged as compared to young SPF mice demonstrated strong signs of naive $\mathrm{T}$ cell decline. While bone marrow is not a major primary entry site for pathogens and antigenic challenges, it represents a location to preserve or stabilize at least a fraction of long-term cellular memory by shielding it from potential bystander activation that is frequently present in secondary lymphoid organs. Additionally, immune cell including $\mathrm{T}$ cell interactions with hematopoietic precursor populations have been shown to maintain and regulate hematopoiesis [53-56]. Absolute cell numbers of total $\mathrm{CD}^{+}$and frequencies of effector as well as CD44 $4^{+}$CD69-expressing TRM CD4 ${ }^{+}$ and $\mathrm{CD} 8^{+} \mathrm{T}$ cells were increased in aged as compared to young SPF mice. In comparison, frequencies of central 
memory $\mathrm{CD}^{+}$and $\mathrm{CD}^{+} \mathrm{T}$ cells were similar in both young and old mice while $\mathrm{CD} 4^{+} \mathrm{CD} 25^{+}$Tregs were decreased in the old group. Notably, we found no changes between young and old SPF mice in frequencies neither of TCR $\beta+$ Natural killer T (NKT) cells nor TCR $\beta^{+}$ CD62L $\mathrm{L}^{+}$NKT cells. In contrast, frequencies of TCR $\beta^{-}$ NKT cells and TCR $\beta^{-}$CD62 $\mathrm{L}^{+}$NKT cells were reduced in the old group in comparison to young SPF (Supplemental Fig. 3C) indicating different compositions of NKT subsets recognizing self and foreign lipids in aged bone marrow environment.

Overall, in the aged compared to young bone marrow we detected on the one hand 1) lower frequencies of pDCs, higher frequencies of monocytes and $\mathrm{PDL}^{+}$macrophages. On the other hand, in the aged compared to young bone marrow we detected 2) lower frequencies of Tregs, higher frequencies of $\mathrm{T}$ effector and TRM while TCM cells and $\operatorname{IgM}^{+}$ASCs remained unaltered. Characterization of single cells acquired at a certain time point with multi-parametric methodologies might potentially lead to misinterpretation regarding immune subsets involved in protection or misestimating of certain parameters in assessment of immune responses. Nevertheless, analysis of such age-related changes between innate and adaptive cells in the BM microenvironment could allow us to better understand possible networks and spatial competitions between memory subsets but also regulations of hematopoiesis in murine and human aged bone marrow niches; for example, under marrow adipose tissue accumulation, marrow remodeling and bone loss which occur during aging [57-59].

In the spleen similar to pet shop mice, old SPF mice revealed a higher frequency of effector and central memory $\mathrm{CD}_{4}^{+}$and $\mathrm{CD}^{+} \mathrm{T}$ cells, which exhibited increased frequencies of effector-cytokine producing $\mathrm{T}$ cells. $\mathrm{CD} 4^{+}$ $\mathrm{CD} 25^{+}$Treg cells were more abundant in the spleen of old SPF mice in comparison to young SPF and pet shop mice. Notably, the decline of naïve $\mathrm{CD} 8^{+}$and $\mathrm{CD} 4^{+} \mathrm{T}$ cells and concomitant increase of Tregs represent some of the most distinctive age associated alterations in cell signatures in both mouse and human $[24,25,60]$. Interestingly, recent results from scRNA-seq have revealed unique complex gene expression signature of $\mathrm{CD}^{+} \mathrm{T}$ cells in aged mice most notably, the aTregs, exhausted, and cytotoxic $\mathrm{CD} 4^{+}$subsets [61]. The $\mathrm{CD} 4^{+}$cytotoxic subset appeared to be dominantly regulated by transcription factors associated with cytotoxicity and $\mathrm{T}$ helper 1 (Th1) polarization, including Eomes, Runx2, Runx3, and $T b \times 21$ regulons which are also required for the cytotoxic CD8 lineage [61, 62]. This result is in line with our effector-cytokine producing $\mathrm{CD}_{4}^{+} \mathrm{T}$ cells data where we observed a significant increase of cytotoxic $\mathrm{CD} 107^{+}$ $\mathrm{CD} 4^{+} \mathrm{T}$ cells and polyfunctional $\mathrm{CD} 107^{+} \mathrm{IFN}^{-} \gamma^{+} \mathrm{CD} 4^{+}$ $\mathrm{T}$ cells lacking typical helper CD40L, IL2 and IL4 expression (Supplemental Fig. 5). Cytotoxic CD4 ${ }^{+}$cells were previously identified and therapeutically used in murine models of cancer and colitis [63, 64] and in healthy humans and human viral infection [62, 65]. However, they have not been comprehensively linked to aging nor $\mathrm{CD} 107^{+}$(LAMP-1) has been directly assessed in that context and while the antigen specificity, differentiation pathways, function, and accumulation of cytotoxic $\mathrm{CD} 4^{+}$cells in aging are yet to be revealed, they may mark a stage in aging with a robust immune failure and chronic inflammation or in contrast an adaptation to the late stage of aging in supercentenarians humans [66].

Even though analyzing multiple organs was not in the scope of our study, age-related changes occur in the cellular composition of both lymphoid and non-lymphoid organs. As expected, our results are in line with published scRNA-seq results from the spleen where the proportion of $\mathrm{T}$ cells decreased with age while the relative amount of plasma cells increased supported by upregulation of $C d 79 a$ and Jchain and the downregulation of $C d 3 d$ [67]. Analysis of clonal relationships between $\mathrm{B}$ cells and $\mathrm{T}$ cells throughout the organism revealed the number of $\mathrm{B}$ cells and $\mathrm{T}$ cells belonging to a clonotype doubled at 18 months $(20-23 \%)$ when compared to young mice indicating an increase in clonality of the $B$ and $\mathrm{T}$ cell repertoire at later ages [67] which is what we hypothesize and expect in our aged SPF mice in comparison to young or pet shop mice. These changes in clonality for both $\mathrm{B}$ cell and $\mathrm{T}$ cell repertoires between young and old mice in parallel with increased innate first line of defenses observed in the pet shop mice are noteworthy because they suggest how the immune system, for example of old mice, is less likely to respond to some pathogens. In parallel to $\mathrm{T}$ cell and $\mathrm{B}$ cell modifications in the spleen the researchers observed alteration in tissue composition of kidney, liver, skin with age in that mice as well as decreased mesenchymal compartments in the bladder with increasing age while the urothelial compartment increased and was infiltrated by a plethora of leukocytes known as age-related urothelial changes. It would be of interest to investigate in the future if our holistic detected aging changes in lymphoid organs such as the bone marrow and spleen correlate to systemic organ alterations and unravel in detail not only the composition but also the mechanisms of the immune system onto age-related organ modifications.

Although SPF mice are an invaluable platform for immunological studies, further research is needed towards establishing murine experimental set-ups that allow more closely emulation of human physiology. One key point is that the immune system of commonly used SPF mice maintains a relatively naïve state throughout the animal's entire life. Accordingly, several immune signatures in SPF mice have similarities to those of neonatal 
humans [11]. While establishing the use of feral or pet shop mice in experimental settings could be challenging to implement, the use of conventional SPF mice challenged with a defined set of physiological infections, may be a suitable compromise in future experimental assessment. Being exposed to "natural" pathogens can induce normalized immune systems, suitable to study immune ageing and diseases similar as in humans, improving immune responses to infections and most notably even accurately phenocopy patient outcomes in clinical trials $[11,68,69]$.

Varying degrees of immune experience in mice can be now controlled through diet, sterile derivation, husbandry practices, and sourcing genetically outbred pet store and feral mice from environments outside of biocontainment. We here show how the age of mice is also a parameter which should be taken into consideration in order to normalize, only to some extent, the immune system. We here highlight specific immune signatures imprinted by accumulating inflammatory events firstly under ageing SPF conditions, such as high abundancy of differentiated T, B and NK cells and notably Tregs and $\mathrm{IgM}^{+}$ASCs. Secondly, distinct alterations are demonstrated under repetitive natural environmental microbial driven conditions, such as high abundancy of differentiated T, B and NK cells and notably 'switched' $\operatorname{IgD}^{-}$IgM $^{-}$ $\mathrm{B}$ cells, granulocytes, $\mathrm{pDCs}, \mathrm{cDCs}$ and monocytes, represented in the pet shop group (Fig. 6). To avoid contamination of inbred lab mouse colonies, we were not able to perform pathogen challenges comparing different groups of SPF with "wild" mice in our facilities. A solution for that would be to perform those experiments under biosafety 3 conditions. Due to this restriction, we assessed solely phenotypic characteristics and short-term functional properties. We cannot exclude that different genetic backgrounds in pet shop mice represent an important factor influencing the differences observed, however, this seems very unlikely considering the fact that pet shop mice are infected by a multitude of pathogens, including viruses, bacteria, and endoparasites [70] .In line with that, our previous experiments comparing three murine groups with the same age sharing the exact same CD45.1, C57BL/6 J genetic background and age (a) SPF laboratory mice, (b) SPF mice housed for 2 months under non-SPF conditions and (c) mice bred in quarantine to (d) pet shop mice, revealed phenotypic and functional differences regarding the "maturity" of their immune system including absolute numbers and frequencies of immune subsets which associated strongly with the degree of pathogenic priming [10]. Particularly, analogous results on our CD45.1, C57BL/6 J quarantine mice indicate that such immune differences are mostly due to the absence of pathogen infection in SPF animals sharing exactly the same genetic background [10].
Nonetheless, due to our staining strategy of surface antigens for mass cytometry using selected monoclonal antibodies we can exclude specific genetic backgrounds for the pet shop group. In particular, the monoclonal ab NK1.1 (clone: PK136) used for the phenotyping of NK cells in our surface mass cytometry panel reacts only with mouse surface antigen NK1.1 in mouse strains such as $\mathrm{C} 57 \mathrm{BL} / 6 \mathrm{~J}, \mathrm{FVB} / \mathrm{N}$ and NZB but not $\mathrm{AKR}, \mathrm{BALB} / \mathrm{c}$, $\mathrm{CBA} / \mathrm{J}, \mathrm{C} 3 \mathrm{H}, \mathrm{DBA} / 1, \mathrm{DBA} / 2$, NOD, SJL, and 129 murine strains which do not express the NK1.1 antigen and instead the clone DX5 should be used [71-74]. Additionally, both pet shop and quarantine mice contained significantly higher frequencies of IFN $\gamma$-producing $\mathrm{CD} 8^{+}$ and $\mathrm{CD}^{+} \mathrm{T}$ cells similarly to our old SPF mice analyzed here as compared to young SPF and non-SPF mice. The percentage of $\mathrm{CD} 4^{+} \mathrm{T}$ cells producing the immunosuppressive cytokine IL-10 was increased in pet shop and quarantine mice, suggesting that immunoregulation by IL-10-producing cells is an essential part of effector T cell immunity against natural pathogens, possibly reducing immunopathology. In addition the frequencies of

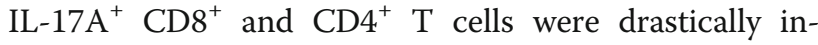
creased in pet shop mice as compared to the other mouse groups from our previous study [10]. In line with these results, independent experiments revealed the secretion of IL-17A and IL-13 was limited to $\mathrm{CD} 40 \mathrm{~L}^{+}$, but not $\mathrm{CD}_{40 \mathrm{~L}^{-}} \mathrm{CD}^{+}$memory $\mathrm{T}$ cells in immune competent pet shop mice from our most recent study [62], while such cells were barely detectable in SPF mice. Considering the strong association between the intestinal microbiota and the priming of IL-17A-producing cells [75], it is reasonable to attribute this increase to differences in the normal microbiota between pet shop mice and lab-housed mice [10].

Differential effects of age on hematopoietic progenitor cell functions, circulating and splenic leukocyte populations have been long known between strains such as C57BL/6 J, BALB/C and D2 mice [76-78]. Numerous reports suggest a preferential bias for the C57BL/6 J mouse strain to develop Th1-type response, whereas for example the BALB/c strain is biased towards a Th2-type cytokine polarization to some infectious agents [76, 7983]. Additionally, TLR signaling and cytokine production in aged monocytes and macrophages has also been shown to be different between the BALB/c and C57BL/ $6 \mathrm{~J}$ strains [84-86]. Nevertheless, similar approaches using young substrain C57BL/6N (in contrast to our case C57BL/6 J) and unidentified background pet shop mice in cohousing experiments showed that microbial exposure enhances immunity to pathogens recognized by TLR2 but increases susceptibility to cytokine storm through TLR4 sensitization [87]. Signatures from the blood of these mice showed similar relations and fluctuations to our young SPF mice and pet shop in particular 
elevated frequencies of CD4+ T cells, monocytes, Ly6G+ granulocytes and decreased frequencies of $\mathrm{B}$ cells in the pet shop group supporting that some major immune cell signatures which we described could be relevant to substrains and even to unidentified genetical backgrounds. Last but not least, we cannot exclude that without comparing aged pet shop mice or/and old SPF mice challenged with a controlled set of pathogens to young and old SPF mice we cannot clearly decipher aging "SPF edited" from pathogen driven immune signatures. More multidimensional immuno-profiling studies are clearly needed including bone marrow but also non lymphoid organ data in different ages of pet shop and other commonly used murine strains physiologically challenged with define microbes during their lifetime to better define and understand $\mathrm{T}$ and $\mathrm{B}$ cell memory subsets but also systemic immune alterations during ageing from physiological pathogen challenges.

\section{Conclusions}

The data presented here demonstrate a) how ageing impacts both innate and adaptive immune cells not only in spleen but also the bone marrow representing a site of origin and migration or selective retention of immune subsets and b) how old SPF mice are characterized by a mature but different immune system in comparison to pet shop mice suggesting that current settings for experimental mouse models should be fine-tuned according to their use in pre-clinical mouse research. Understanding how ageing impacts both the innate and adaptive immune cells while distinguishing alterations from physiological pathogen challenges is critical for designing effective vaccines and immunotherapies which could possibly overcome age-dependent refractory diseases. To maximize prospects to translate novel treatments from preclinical to translational research we should further explore the possibilities of improving mouse models by selectively using immune experienced mice to our repertoire of investigative tools while adapting common SPF housing conditions as a more relevant physiological human setting $[11,68,69]$.

\section{Methods}

\section{Mice}

In this study, three experimental groups were used: young/middle-aged (6 months) and old (18-20 months) mice kept specific pathogen-free (SPF) and pet shopsupplied mice. For the SPF groups, CD45.1 mice with a C57BL/6 J background were bred in house under SPF conditions at the Charités animal housing facility. In all facilities of the Charité's animal housing, health monitoring is performed regularly according to the guidelines of the Federation of European Laboratory Animal Science Associations (FELASA). Pet shop mice, as a surrogate for wild mice, weighted over $25 \mathrm{~g}$ and were purchased from an authorized vendor. All mice were used in accordance with the German law for animal protection with permission of the local authorities.

\section{Generation of single-cell suspensions of the spleen and bone marrow}

Mice were anesthetized with isoflurane followed by cervical dislocation. Spleens and the right hinge were harvested. Single-cell suspensions of the spleen were prepared by smashing each organ through a $70 \mu \mathrm{m}$ cell strainer. Single-cell suspensions of the bone marrow were prepared into a falcon tube by flushing the shaft using a syringe with a needle. Erythrocytes for both spleen and bone marrow were lysed with $2 \mathrm{ml} \mathrm{ACK} \mathrm{lys-}$ ing buffer (Thermo Fisher Scientific) for $4 \mathrm{~min}$ at room temperature (RT). Reaction was stopped with $9 \mathrm{ml}$ PBS $0.1 \%$ BSA and suspension was passed through a $30 \mu \mathrm{m}$ cell strainer. After centrifugation (8 min at $310 \mathrm{~g}$ at RT) cell pellet was resuspended and incubated for $5 \mathrm{~min}$ in 5 $\mathrm{ml}$ warm complete culture medium (RPMI containing $10 \%$ FBS, $100 \mathrm{U} / \mathrm{ml}$ penicillin (Biochrom), $100 \mathrm{mg} / \mathrm{ml}$ streptomycin (Biochrom), with $25 \mathrm{U} / \mathrm{ml}$ Pierce Universal Nuclease (Thermo Fischer Scientific) in order to reduce viscosity and background from free DNA from any lysed cells. Absolute counts of each suspension were performed on a MACSQuant (Miltenyi Biotec) flow cytometer by acquisition of a defined volume of the cell suspension and counting of $\mathrm{CD} 45^{+}, \mathrm{CD} 19^{+}$and $\mathrm{CD} 3^{+}$ events.

\section{Staining of surface antigens for mass cytometry and sample acquisition}

Staining of surface antigens for mass cytometry was performed as described before [10]. Four new unlabelled carrier protein-free antibodies (abs) were purchased from BD Biosciences (San Jose, CA) or BioLegend (SanDiego, $\mathrm{CA}$ ) as described below and were conjugated with metal isotopes using Maxpar Ab labeling kits (Fluidigm) according to the manufacturer's instructions. Metal conjugated abs 162Dy-CXCR4 (clone L276F12, Biolegend), 166Er-CD95 (clone Jo2, BD biosciences), 167Er-CD127 (clone A7R34, Biolegend) and 174Yb-GL7 (clone GL7, Biolegend) were added to the previously established murine surface antigens panel [10]. Cells were acquired on a CyTOF2 mass cytometer upgraded to Helios specifications (CyTOF2/Helios) (Fluidigm). The $0.1 \times \mathrm{EQ}$ Four Element Calibration Beads (Fluidigm) were added to the samples for data normalization of the FCS files using the CyTOF software. 330.000 events were recorded in total per file. Tuning was performed each day before measurement following manufacture's guidelines. 
Polyclonal stimulation and intracellular cytokine staining A total of $5 \times 10^{6}$ splenocytes per sample in $1 \mathrm{ml}$ complete culture medium (RPMI containing 10\% FBS, $100 \mathrm{U} / \mathrm{ml}$ penicillin (Biochrom), $100 \mu \mathrm{g} / \mathrm{ml}$ streptomycin (Biochrom), and $50 \mu \mathrm{M}$ 2-mercaptoethanol (Gibco) were polyclonally stimulated for $5 \mathrm{~h}$ with $0.01 \mathrm{mg} / \mathrm{ml}$ phorbolmyristateacetate (PMA, Sigma) and $1 \mathrm{mg} / \mathrm{ml}$ ionomycin (Sigma), or left untreated, both in the presence of 0.01 $\mathrm{mg} / \mathrm{ml}$ brefeldin A (Sigma). After incubation, cells were washed twice with PBS and LIVE/DEAD ${ }^{\circ}$ Fixable Aqua Dead cell stain kit (Thermo Fischer Scientific) was used to enable exclusion of dead cells. Intracellular cytokines IFN- $\gamma$ (clone: XMG1.2-PE/Cy7, Biolegend), IL-2 (clone: JES6-5H4-APC, Biolegend), IL-4 (11B11-Pe, Biolegend), TNF- $\alpha$ (clone: MP6-XT22-Alexa Fluor 700, Biolegend), IL-10 (clone: JES5-16E3- APC/Cyanine7, Biolegend) CD4 (clone: GK1.5-Brilliant Violet 605, Biolegend), CD8 (clone: 53-6.7-PerCP/Cyanine5.5, Biolegend) and CD40L (clone: MR1-FITC, Invitrogen) staining was performed using fluorochrome-conjugated antibodies for $30 \mathrm{~min}$ at $4{ }^{\circ} \mathrm{C}$ after fixation and permeabilization with FACS-Lysing and FACS-Perm2 Solution (BD) according to the manufacturer's protocol. The cells were subsequently analysed using a BD LSR-II cytometer. For CD107 $\alpha$ staining, CD107 $\alpha$ (clone: 1D4B-efluor 450, eBioscience) was added during stimulation. FACS data were analyzed using FlowJo 9.

\section{Mass cytometry data analysis}

Cytobank [13] was used for initial manual gating and semi-automated SPADE and viSNE to generate spade trees and t-SNE maps accordingly [13-15]. FCS files were pre-processed by manually gating, excluding calibration beads, on cellular events on DNA intercalators, event length, cis-platin and TER119, to remove debris, doublets, normalization beads, live cells and erythrocytes. viSNE analysis was performed on intact, viable cisplatin-, CD $45^{+}$leukocytes, files were exported and then concatenated using FlowJo 10 visualizing on each tSNE blot same cell event counts. Global lineage 2D t-SNE map and SPADE clustering were generated using CD3, CD11c, CD69, IgM, CD11b, CD19, CD138, CD25, Ly6G, Ly6C, MHCII, PD-L1, CD80, CD86, CD62L, CD40, IgD, CD83, PD-L2, CD8, TCR $\beta$, NK1.1, CD44, CD4, F4/80, CD38 and B220 as clustering markers after gating on single viable intact $\mathrm{CD} 45^{+}$leukocytes for all three mouse groups. Based on the median expression of lineage markers CD3, CD11b, TCR $\beta$, CD4, CD8, CD138, CD19, B220 and NK1.1 major immune subsets 1) CD45 $5^{+}$ $\mathrm{CD}_{138^{-}} \mathrm{CD}^{-} \mathrm{TCR}^{-} \mathrm{CD}^{-} 9^{-}$innate cells, 2) $\mathrm{CD}^{-} 5^{+}$ $\mathrm{CD}_{19}{ }^{+} \mathrm{B}_{220}{ }^{+} \mathrm{B}$ cells, 3) $\mathrm{CD}_{4} 5^{+} \mathrm{CD}^{+} \mathrm{T}$ cells were manually defined. The three major SPADE-clustered subsets 1) innate cells, 2) B cells and 3) T cells were then subjected to viSNE mapping based on lineage-specific differentiation markers.

To generate t-SNE maps for the innate compartment, channels for the following markers were selected to run viSNE: CD11c, CD69, CD11b, CD25, Ly6G, Ly6C, MHCII, PD-L1, CD80, CD86, CD62L, CD40, CD83, PDL2, CD8, NK1.1, CD44, CD4, F4/80 and CD38. The B cell differentiation viSNE markers included: CD11c, CD69, IgM, CD11b, CD19, CD138, Ly-6C, MHCII, PDL1, CD80, CD86, CD62L, CD40, IgD, CD83, PD-L2, CD44, F4/80, CD38 and B220. To generate t-SNE maps for the $\mathrm{T}$ cell compartment, channels for the following markers were selected to run viSNE: CD11c, CD69, CD11b, CD25, Ly6G, Ly6C, MHCII, PD-L1, CD80, CD86, CD62L, CD83, PD-L2, CD8, TCR $\beta$, NK1.1, CD44, CD4, F4/80 and CD38.

Heatmaps (Figs. 1, 2, 3, 4) were generated using cytobank and show calculated transformed ratio of median marker intensities by table's minimum within each cell population with global scale range. R, version 3.1, 2017 was used for hierarchical cluster analysis and generating a heat map (Fig. 6b). Spearman correlation distance matrices of population frequencies served as input for Wards agglomerative hierarchical clustering [88]. Heat map coloring was scaled per row, i.e. represents z-scores of population frequencies.

\section{Statistical analysis}

Statistical analysis was performed using Prism (GraphPad Software, SanDiego, CA). Cell numbers and frequencies recovered from spleen and bone marrow were compared using the Mann-Whitney test. $P$ values of less than 0.05 were considered significant.

\section{Supplementary Information}

The online version contains supplementary material available at https://doi. org/10.1186/s12979-021-00230-3.

Additional file 1: Figure S1. Gating strategy for single live TER119CD45+ cells. Figure S2. Leukocyte composition in spleen and bone marrow ofyoung and old SPF mice. Relative distributions of immune cell subsets identified withinCD45+ leukocytes for spleen and bone marrow (per hinge) respectively. Median subsetproportions are shown for each group as stacked bars (100\% CD45). Figure S3. Immune populations in the bone marrow of young and old SPF mice. (A) Innate, (B) B, (C) NKT and ( $D \& E$ ) T cell subsets respectively. (B left) Representative gating strategy for developmental stages of single live TER119- CD45+ CD138CD3- TCRß- NK1.1- B220+ CD19+ B cells. (C) TCR $3+$ and TCR $\beta-$ Natural killer T (NKT) cells. (D) Representative histograms of CD8+ T cells depict the expression of the indicated surface molecules on Tnaive, TCM, Teff and TRM respectively. Line indicates mean, \pm SD is depicted. ${ }^{* *} P<0.01$ *** $P<0.001$ Mann-Whitney test. NS indicates non-significant changes. Figure S4. Immune signatures in the spleen that distinguish young and old SPF mice versus pet shop mice. (A-C) Frequencies of Innate, B and T subsets respectively that are highest in the pet shop mice among all three groups. (D) Frequencies of cell subsets that are lowest in the pet shop mice among all three groups. (E) Frequencies of CD8+ TCm cells among all three groups. Line indicates mean, \pm SD is depicted. ${ }^{*} P<0.05$, ${ }^{* *} P<0.01{ }^{* * *} P<0.001$ Mann-Whitney test. Figure S5. Identification of 
poly-functional CD4+ (A) and CD8+ (B) T cells by Boolean gating. Line indicates mean, \pm SD is depicted. ${ }^{*} P<0.05$, ${ }^{* *} P<0.01{ }^{* * *} P<0.001$ MannWhitney test

\section{Acknowledgements}

$\mathrm{CN}$ is a member of the Berlin-Brandenburg School for Regenerative Therapies (BSRT), Graduate School 203 of the DFG Excellence Initiative.

\section{Authors' contributions}

$\mathrm{CN}$ conceived, designed and performed the experiments, acquired, analyzed, interpreted the data, wrote and edited the manuscript. KM was a major contributor in performing experiments and editing the manuscript. ASJ was a contributor in performing experiments and editing the manuscript. SS was a contributor in analyzing data. DK acquired data. NM planned and designed animal ethical approvals. MF obtained funding interpreted the data and edited the manuscript. AT conceived and supervised the project, obtained funding, wrote and edited the manuscript. All authors read and approved the final manuscript.

\section{Funding}

This work was supported by DFG/Charite (Grant number: INST335/453-1). Open Access funding enabled and organized by Projekt DEAL.

\section{Availability of data and materials}

The datasets used and/or analyzed during the current study are available from the corresponding author on reasonable request.

\section{Declarations}

\section{Ethics approval and consent to participate}

In all facilities of the Charité's animal housing, health monitoring is performed regularly according to the guidelines of the Federation of European Laboratory Animal Science Associations (FELASA). All mice were used in accordance with the German law for animal protection with permission of the local authorities.

\section{Consent for publication}

Not applicable.

\section{Competing interests}

The authors declare that they have no competing interests.

\section{Author details}

'Regenerative Immunology and Aging, BIH Center for Regenerative Therapies (BCRT), Charité Universitätsmedizin Berlin, Berlin, Germany. ${ }^{2}$ Institute for Medical Immunology, Charité Universitätsmedizin Berlin, Berlin, Germany. ${ }^{3}$ Berlin-Brandenburg School for Regenerative Therapies (BSRT), Charité Universitätsmedizin Berlin, Berlin, Germany. ${ }^{4}$ Flow \& Mass Cytometry Core Facility, Charité - Universitätsmedizin Berlin and Berlin Institute of Health (BIH), Berlin, Germany.

Received: 16 October 2020 Accepted: 26 March 2021

Published online: 20 April 2021

\section{References}

1. Gavazzi G, Krause KH. Ageing and infection. Lancet Infect Dis. 2002;2(11): 659-66. https://doi.org/10.1016/S1473-3099(02)00437-1.

2. Goronzy JJ, Weyand CM. Immune aging and autoimmunity. Cell Mol Life Sci. 2012;69(10):1615-23. https://doi.org/10.1007/s00018-012-0970-0.

3. Hakim FT, Flomerfelt FA, Boyiadzis M, Gress RE. Aging, immunity and cancer. Curr Opin Immunol. 2004;16(2):151-6. https://doi.org/10.1016/j. coi.2004.01.009

4. Vilas JM, Carneiro C, Da Silva-Alvarez S, Ferreiros A, Gonzalez P, Gomez M, et al. Adult Sox2+ stem cell exhaustion in mice results in cellular senescence and premature aging. Aging Cell. 2018;17(5):e12834. https://doi. org/10.1111/acel.12834

5. Lopez-Otin C, Blasco MA, Partridge L, Serrano M, Kroemer G. The hallmarks of aging. Cell. 2013;153(6):1194-217. https://doi.org/10.1016/j. cell.2013.05.039
6. Xia S, Zhang X, Zheng S, Khanabdali R, Kalionis B, Wu J, et al. An update on Inflamm-aging: mechanisms, prevention, and treatment. J Immunol Res. 2016;2016:8426874.

7. Zhao Q, Elson CO. Adaptive immune education by gut microbiota antigens. Immunology. 2018;154(1):28-37. https://doi.org/10.1111/imm.12896.

8. Padgett DA, Glaser R. How stress influences the immune response. Trends Immunol. 2003;24(8):444-8. https://doi.org/10.1016/S1471-4906(03)00173-X.

9. MacGillivray DM, Kollmann TR. The role of environmental factors in modulating immune responses in early life. Front Immunol. 2014;5:434.

10. Japp AS, Hoffmann K, Schlickeiser S, Glauben R, Nikolaou C, Maecker HT, et al. Wild immunology assessed by multidimensional mass cytometry. Cytometry A. 2017;91(1):85-95. https://doi.org/10.1002/cyto.a.22906.

11. Beura LK, Hamilton SE, Bi K, Schenkel JM, Odumade OA, Casey KA, et al. Normalizing the environment recapitulates adult human immune traits in laboratory mice. Nature. 2016;532(7600):512-6. https://doi.org/10.1038/na ture17655.

12. Abolins SR, Pocock MJ, Hafalla JC, Riley EM, Viney ME. Measures of immune function of wild mice, Mus musculus. Mol Ecol. 2011;20(5):881-92. https:// doi.org/10.1111/j.1365-294X.2010.04910.x.

13. Kotecha N, Krutzik PO, Irish JM. Web-based analysis and publication of flow cytometry experiments. Curr Protoc Cytom. 2010;Chapter 10:Unit10 7.

14. Qiu P, Simonds EF, Bendall SC, Gibbs KD Jr, Bruggner RV, Linderman $M D$, et al. Extracting a cellular hierarchy from high-dimensional cytometry data with SPADE. Nat Biotechnol. 2011;29(10):886-91. https:// doi.org/10.1038/nbt.1991.

15. el Amir AD, Davis KL, Tadmor MD, Simonds EF, Levine JH, Bendall SC, et al. viSNE enables visualization of high dimensional single-cell data and reveals phenotypic heterogeneity of leukemia. Nat Biotechnol. 2013;31(6):545-52.

16. van der Maaten L, Hinton G. Visualizing Data using t-SNE. J Mach Learn Res. 2008;9:2579-605.

17. Loke P, Allison JP. PD-L1 and PD-L2 are differentially regulated by Th1 and Th2 cells. Proc Natl Acad Sci U S A. 2003;100(9):5336-41. https://doi.org/10.1 073/pnas.0931259100.

18. Linton PJ, Dorshkind K. Age-related changes in lymphocyte development and function. Nat Immunol. 2004:5(2):133-9. https://doi.org/10.1038/ni1033.

19. Miller JP, Allman D. The decline in B lymphopoiesis in aged mice reflects loss of very early B-lineage precursors. J Immunol. 2003;171(5):2326-30. https://doi.org/10.4049/jimmunol.171.5.2326.

20. Kline GH, Hayden TA, Klinman NR. B cell maintenance in aged mice reflects both increased B cell longevity and decreased B cell generation. J Immunol. 1999:162(6):3342-9.

21. Ma S, Wang C, Mao X, Hao Y. B cell dysfunction associated with aging and autoimmune diseases. Front Immunol. 2019;10:318. https://doi.org/10.3389/ fimmu.2019.00318.

22. Johnson KM, Owen K, Witte PL. Aging and developmental transitions in the B cell lineage. Int Immunol. 2002;14(11):1313-23. https://doi.org/10.1093/ intimm/dxf092.

23. Tokoyoda K, Zehentmeier S, Chang HD, Radbruch A. Organization and maintenance of immunological memory by stroma niches. Eur J Immunol. 2009:39(8):2095-9. https://doi.org/10.1002/eji.200939500.

24. George AJ, Ritter MA. Thymic involution with ageing: obsolescence or good housekeeping? Immunol Today. 1996;17(6):267-72. https://doi.org/10.1016/ 0167-5699(96)80543-3.

25. Lynch HE, Goldberg GL, Chidgey A, Van den Brink MR, Boyd R, Sempowski GD. Thymic involution and immune reconstitution. Trends Immunol. 2009; 30(7):366-73. https://doi.org/10.1016/j.it.2009.04.003.

26. Murray JM, Kaufmann GR, Hodgkin PD, Lewin SR, Kelleher AD, Davenport MP, et al. Naive T cells are maintained by thymic output in early ages but by proliferation without phenotypic change after age twenty. Immunol Cell Biol. 2003;81(6):487-95. https://doi.org/10.1046/ j.1440-1711.2003.01191.x.

27. Marshall HD, Chandele A, Jung YW, Meng H, Poholek AC, Parish IA, et al. Differential expression of Ly6C and T-bet distinguish effector and memory Th1 CD4(+) cell properties during viral infection. Immunity. 2011;35(4):63346. https://doi.org/10.1016/j.immuni.2011.08.016.

28. Walunas TL, Bruce DS, Dustin L, Loh DY, Bluestone JA. Ly-6C is a marker of memory CD8+ T cells. J Immunol. 1995;155(4):1873-83.

29. Hanninen A, Maksimow M, Alam C, Morgan DJ, Jalkanen S. Ly6C supports preferential homing of central memory CD8+ T cells into lymph nodes. Eur J Immunol. 2011;41(3):634-44. https://doi.org/10.1002/eji.201040760. 
30. Baliu-Pique M, Verheij MW, Drylewicz J, Ravesloot L, de Boer RJ, Koets A, et al. Short lifespans of memory T-cells in bone marrow, blood, and lymph nodes suggest that T-cell memory is maintained by continuous self-renewa of recirculating cells. Front Immunol. 2018;9:2054. https://doi.org/10.3389/ fimmu.2018.02054

31. Chang HD, Tokoyoda K, Radbruch A. Immunological memories of the bone marrow. Immunol Rev. 2018;283(1):86-98. https://doi.org/10.1111/imr.12656.

32. Siracusa F, McGrath MA, Maschmeyer P, Bardua M, Lehmann K, Heinz G, et al. Nonfollicular reactivation of bone marrow resident memory CD4 T cells in immune clusters of the bone marrow. Proc Natl Acad Sci U S A. 2018;115(6):1334-9. https://doi.org/10.1073/pnas.1715618115.

33. Siracusa F, Durek P, McGrath MA, Sercan-Alp O, Rao A, Du W, et al. CD69(+) memory $T$ lymphocytes of the bone marrow and spleen express the signature transcripts of tissue-resident memory T lymphocytes. Eur J Immunol. 2019:49(6):966-8. https://doi.org/10.1002/eji.201847982.

34. Bohannon C, Powers R, Satyabhama L, Cui A, Tipton C, Michaeli M, et al. Long-lived antigen-induced IgM plasma cells demonstrate somatic mutations and contribute to long-term protection. Nat Commun. 2016;7(1): 11826. https://doi.org/10.1038/ncomms11826.

35. Masopust D, Sivula CP, Jameson SC. Of mice, dirty mice, and men: using mice to understand human immunology. J Immunol. 2017;199(2):383-8. https://doi.org/10.4049/jimmunol.1700453.

36. Claesson MJ, Jeffery IB, Conde S, Power SE, O'Connor EM, Cusack S, et al. Gut microbiota composition correlates with diet and health in the elderly. Nature. 2012;488(7410):178-84. https://doi.org/10.1038/nature11319.

37. Ericsson AC, Gagliardi J, Bouhan D, Spollen WG, Givan SA, Franklin CL. The influence of caging, bedding, and diet on the composition of the microbiota in different regions of the mouse gut. Sci Rep. 2018;8(1):4065. https://doi.org/10.1038/s41598-018-21986-7.

38. Stappenbeck TS, Virgin HW. Accounting for reciprocal host-microbiome interactions in experimental science. Nature. 2016;534(7606):191-9. https:// doi.org/10.1038/nature18285.

39. Gordon HA, Bruckner-Kardoss E, Wostmann BS. Aging in germ-free mice: life tables and lesions observed at natural death. J Gerontol. 1966;21(3):380-7. https://doi.org/10.1093/geronj/21.3.380.

40. Fransen F, van Beek AA, Borghuis T, Aidy SE, Hugenholtz F, van der Gaastde Jongh $C$, et al. Aged gut microbiota contributes to Systemical Inflammaging after transfer to germ-free mice. Front Immunol. 2017:8:1385. https://doi.org/10.3389/fimmu.2017.01385.

41. Pettan-Brewer C, Treuting PM. Practical pathology of aging mice. Pathobiol Aging Age Relat Dis. 2011;1. https://doi.org/10.3402/pba.v1i0.7202.

42. Toth LA. Identifying and implementing endpoints for geriatric mice. Comp Med. 2018;68(6):439-51. https://doi.org/10.30802/AALAS-CM-18-000022.

43. Li Y, Konicki WS, Wright JT, Suggs $\mathrm{C}$, Xue H, Kuehl MA, et al. Mouse genetic background influences the dental phenotype. Cells Tissues Organs. 2013; 198(6):448-56. https://doi.org/10.1159/000360157.

44. Pugach MK, Gibson CW. Analysis of enamel development using murine model systems: approaches and limitations. Front Physiol. 2014;5:313.

45. Juelke K, Killig M, Luetke-Eversloh M, Parente E, Gruen J, Morandi B, et al. CD62L expression identifies a unique subset of polyfunctional CD56dim NK cells. Blood. 2010;116(8):1299-307. https://doi.org/10.1182/ blood-2009-11-253286.

46. Salminen A, Kaarniranta K, Kauppinen A. Inflammaging: disturbed interplay between autophagy and inflammasomes. Aging. 2012;4(3):166-75. https:// doi.org/10.18632/aging.100444.

47. Ding L, Chen T, Wang XJ, Zhou L, Shi AC, Ning Q. CD69+NK cells contribute to the murine hepatitis virus strain 3-induced murine hepatitis. J Huazhong Univ Sci Technol Med Sci. 2013;33(4):505-10. https://doi.org/10.1007/s11596013-1150-7.

48. Cuff AO, Perchet T, Dertschnig S, Golub R, Male V. Tbet promotes CXCR6 expression in immature natural killer cells and natural killer cell egress from the bone marrow. Immunology. 2020;161(1):28-38. https://doi.org/10.1111/ imm.13204.

49. Jenne CN, Enders A, Rivera R, Watson SR, Bankovich AJ, Pereira JP, et al. Tbet-dependent S1P5 expression in NK cells promotes egress from lymph nodes and bone marrow. J Exp Med. 2009;206(11):2469-81. https://doi.org/1 0.1084/jem.20090525.

50. Lugthart G, Melsen JE, Vervat C, van Ostaijen-Ten Dam MM, Corver WE, Roelen DL, et al. Human lymphoid tissues harbor a distinct CD69+CXCR6+ NK cell population. J Immunol. 2016;197(1):78-84. https://doi.org/10.4049/ jimmunol.1502603.
51. Miller JP, Cancro MP. B cells and aging: balancing the homeostatic equation. Exp Gerontol. 2007;42(5):396-9. https://doi.org/10.1016/j.exger.2 007.01.010.

52. Goodnow CC, Adelstein S, Basten A. The need for central and peripheral tolerance in the B cell repertoire. Science. 1990;248(4961):1373-9. https:// doi.org/10.1126/science.2356469.

53. Geerman S, Nolte MA. Impact of T cells on hematopoietic stem and progenitor cell function: good guys or bad guys? World J Stem Cells. 2017; 9(2):37-44. https://doi.org/10.4252/wjsc.v9.i2.37.

54. Fischer L, Herkner C, Kitte R, Dohnke S, Riewaldt J, Kretschmer K, et al. Foxp3(+) regulatory $T$ cells in bone and hematopoietic homeostasis. Front Endocrinol (Lausanne). 2019;10:578.

55. Zhang J, Supakorndej T, Krambs JR, Rao M, Abou-Ezzi G, Ye RY, et al. Bone marrow dendritic cells regulate hematopoietic stem/progenitor cell trafficking. J Clin Invest. 2019:129(7):2920-31. https://doi.org/10.1172/JCl124829.

56. Geerman S, Brasser G, Bhushal S, Salerno F, Kragten NA, Hoogenboezem M, et al. Memory CD8(+) T cells support the maintenance of hematopoietic stem cells in the bone marrow. Haematologica. 2018;103(6):e230-e3. https://doi.org/10.3324/haematol.2017.169516.

57. Ambrosi TH, Scialdone A, Graja A, Gohlke S, Jank AM, Bocian C, et al. Adipocyte accumulation in the bone marrow during obesity and aging impairs stem cell-based hematopoietic and bone regeneration. Cell Stem Cell. 2017;20(6):771-84 e6. https://doi.org/10.1016/j.stem.2017.02.009.

58. Ho YH, Del Toro R, Rivera-Torres J, Rak J, Korn C, Garcia-Garcia A, et al. Remodeling of bone marrow hematopoietic stem cell niches promotes myeloid cell expansion during premature or physiological aging. Cell Stem Cell. 2019;25(3):407-18 e6. https://doi.org/10.1016/j.stem.2019.06.007.

59. Ferguson VL, Ayers RA, Bateman TA, Simske SJ. Bone development and agerelated bone loss in male C57BL/6J mice. Bone. 2003;33(3):387-98. https:// doi.org/10.1016/S8756-3282(03)00199-6.

60. Raynor J, Lages CS, Shehata H, Hildeman DA, Chougnet CA. Homeostasis and function of regulatory T cells in aging. Curr Opin Immunol. 2012;24(4): 482-7. https://doi.org/10.1016/j.coi.2012.04.005.

61. Elyahu Y, Hekselman I, Eizenberg-Magar I, Berner O, Strominger I, Schiller M, et al. Aging promotes reorganization of the CD4 T cell landscape toward extreme regulatory and effector phenotypes. Sci Adv. 2019;5(8):eaaw8330.

62. Loyal L, Warth S, Jurchott K, Molder F, Nikolaou C, Babel N, et al. SLAMF7 and IL-6R define distinct cytotoxic versus helper memory CD8(+) T cells. Nat Commun. 2020;11(1):6357. https://doi.org/10.1038/s41467-020-19002-6.

63. Mucida D, Husain MM, Muroi S, van Wijk F, Shinnakasu R, Naoe Y, et al. Transcriptional reprogramming of mature CD4(+) helper T cells generates distinct MHC class II-restricted cytotoxic T Iymphocytes. Nat Immunol. 2013; 14(3):281-9. https://doi.org/10.1038/ni.2523.

64. Quezada SA, Simpson TR, Peggs KS, Merghoub T, Vider J, Fan X, et al. Tumor-reactive CD4(+) T cells develop cytotoxic activity and eradicate large established melanoma after transfer into lymphopenic hosts. J Exp Med. 2010;207(3):637-50. https://doi.org/10.1084/jem.20091918.

65. Patil VS, Madrigal A, Schmiedel BJ, Clarke J, O'Rourke P, de Silva AD, et al. Precursors of human CD4(+) cytotoxic T lymphocytes identified by singlecell transcriptome analysis. Sci Immunol. 2018;3(19):eaan8664

66. Hashimoto K, Kouno T, Ikawa T, Hayatsu N, Miyajima Y, Yabukami H, et al. Single-cell transcriptomics reveals expansion of cytotoxic CD4 T cells in supercentenarians. Proc Natl Acad Sci U S A. 2019;116(48):24242-51. https:// doi.org/10.1073/pnas.1907883116.

67. Tabula MC. A single-cell transcriptomic atlas characterizes ageing tissues in the mouse. Nature. 2020;583(7817):590-5.

68. Rosshart SP, Vassallo BG, Angeletti D, Hutchinson DS, Morgan AP, Takeda K, et al. Wild mouse gut microbiota promotes host fitness and improves disease resistance. Cell. 2017;171(5):1015-28 e13. https://doi.org/10.1016/j. cell.2017.09.016

69. Rosshart SP, Herz J, Vassallo BG, Hunter A, Wall MK, Badger JH, et al. Laboratory mice born to wild mice have natural microbiota and model human immune responses. Science. 2019;365(6452):eaaw4361.

70. Dammann P, Hilken G, Hueber B, Kohl W, Bappert MT, Mahler M. Infectious microorganisms in mice (Mus musculus) purchased from commercial pet shops in Germany. Lab Anim. 2011;45(4):271-5. https:// doi.org/10.1258/la.2011.010183.

71. Carlyle JR, Mesci A, Ljutic B, Belanger S, Tai LH, Rousselle E, et al. Molecular and genetic basis for strain-dependent NK1.1 alloreactivity of mouse NK cells. J Immunol. 2006;176(12):7511-24. https://doi.org/10.404 9/jimmunol.176.12.7511. 
72. Koo GC, Peppard JR. Establishment of monoclonal anti-Nk-1.1 antibody. Hybridoma. 1984;3(3):301-3. https://doi.org/10.1089/hyb.1984.3.301.

73. Glimcher L, Shen FW, Cantor H. Identification of a cell-surface antigen selectively expressed on the natural killer cell. J Exp Med. 1977;145(1):1-9. https://doi.org/10.1084/jem.145.1.1.

74. Kung SK, Su RC, Shannon J, Miller RG. Characterization of four new monoclonal antibodies that recognize mouse natural killer activation receptors. Hybridoma. 2001;20(2):91-101. https://doi.org/10.1089/02724 570152057580.

75. Ivanov II, Atarashi K, Manel N, Brodie EL, Shima T, Karaoz U, et al. Induction of intestinal Th17 cells by segmented filamentous bacteria. Cell. 2009;139(3): 485-98. https://doi.org/10.1016/j.cell.2009.09.033.

76. Pinchuk LM, Filipov NM. Differential effects of age on circulating and splenic leukocyte populations in C57BL/6 and BALB/C male mice. Immun Ageing. 2008:5(1):1. https://doi.org/10.1186/1742-4933-5-1.

77. Clementi M, Forabosco P, Amadori A, Zamarchi R, De Silvestro G, Di Gianantonio E, et al. CD4 and CD8 T lymphocyte inheritance. Evidence for major autosomal recessive genes. Hum Genet. 1999;105(4):337-42. https:/ doi.org/10.1007/s004399900140.

78. Kraal G, Weissman IL, Butcher EC. Genetic control of T-cell subset representation in inbred mice. Immunogenetics. 1983;18(6):585-92. https:// doi.org/10.1007/BF00345966.

79. von Stebut E, Belkaid Y, Nguyen BV, Cushing M, Sacks DL, Udey MC. Leishmania major-infected murine langerhans cell-like dendritic cells from susceptible mice release IL-12 after infection and vaccinate against experimental cutaneous Leishmaniasis. Eur J Immunol. 2000;30(12):3498506. https://doi.org/10.1002/1521-4141(2000012)30:12<3498::AID-IMMU34 98>3.0.CO;2-6.

80. Misslitz AC, Bonhagen K, Harbecke D, Lippuner C, Kamradt T, Aebischer T. Two waves of antigen-containing dendritic cells in vivo in experimental Leishmania major infection. Eur J Immunol. 2004;34(3):715-25. https://doi. org/10.1002/eji.200324391.

81. Pinto EF, de Mello CM, Rossi-Bergmann B. Interferon-gamma-inducing oral vaccination with Leishmania amazonensis antigens protects $B A L B / C$ and C57BL/6 mice against cutaneous leishmaniasis. Vaccine. 2003;21(25-26): 3534-41. https://doi.org/10.1016/S0264-410X(03)00427-4.

82. Ritchie AJ, Yam AO, Tanabe KM, Rice SA, Cooley MA. Modification of in vivo and in vitro T- and B-cell-mediated immune responses by the Pseudomonas aeruginosa quorum-sensing molecule $\mathrm{N}$-(3-oxododecanoyl)L-homoserine lactone. Infect Immun. 2003;71(8):4421-31. https://doi.org/1 0.1128/IAI.71.8.4421-4431.2003.

83. Gemmell E, Winning TA, Carter CL, Ford PJ, Bird PS, Ashman RB, et al. Differences in mouse strain influence leukocyte and immunoglobulin phenotype response to Porphyromonas gingivalis. Oral Microbiol Immunol. 2003;18(6):364-70. https://doi.org/10.1046/j.0902-0055.2002.00098.x.

84. Renshaw M, Rockwell J, Engleman C, Gewirtz A, Katz J, Sambhara S. Cutting edge: impaired toll-like receptor expression and function in aging. J Immunol. 2002:169(9):4697-701. https://doi.org/10.4049/immunol.169.9.4697. J

85. Boehmer ED, Meehan MJ, Cutro BT, Kovacs EJ. Aging negatively skews macrophage TLR2- and TLR4-mediated pro-inflammatory responses without affecting the IL-2-stimulated pathway. Mech Ageing Dev. 2005;126(12): 1305-13. https://doi.org/10.1016/j.mad.2005.07.009

86. Shaw AC, Joshi S, Greenwood H, Panda A, Lord JM. Aging of the innate immune system. Curr Opin Immunol. 2010;22(4):507-13. https://doi.org/10.1 016/j.coi.2010.05.003.

87. Huggins MA, Sjaastad FV, Pierson M, Kucaba TA, Swanson W, Staley C, et al. Microbial exposure enhances immunity to pathogens recognized by TLR2 but increases susceptibility to cytokine storm through TLR4 sensitization. Cell Rep. 2019;28(7):1729-43 e5. https://doi.org/10.1016/j.celrep.2019.07.028.

88. van Dongen S, Enright AJ. Metric distances derived from cosine similarity and Pearson and Spearman correlations. arXiv e-prints. 2012. Available from: https://ui.adsabs.harvard.edu/abs/2012arXiv1208.3145V.

\section{Publisher's Note}

Springer Nature remains neutral with regard to jurisdictional claims in published maps and institutional affiliations.

\section{Ready to submit your research? Choose BMC and benefit from}

- fast, convenient online submission

- thorough peer review by experienced researchers in your field

- rapid publication on acceptance

- support for research data, including large and complex data types

- gold Open Access which fosters wider collaboration and increased citations

- maximum visibility for your research: over $100 \mathrm{M}$ website views per year

At $\mathrm{BMC}$, research is always in progress.

Learn more biomedcentral.com/submissions 